\title{
الموضوعية في دراسة الأديان
}

* عامر الحافي

مقدمة:

تقفُ مشكلةُ غياب الموضوعية في دراسة الأديان، في صدارة المشكلات العلمية التي تواجه الباحث المنصف، فهي تؤثر في منهج الدراسة ونتائجها، وتؤدِّي إلى اختزال دراسة الأديان للبحث عن العيوب والمتناقضات والمتشابهات.

إنَّ دراسـة الأديـان الأخـرى دراسـةً موضـوعية يؤسِّس لبنـاء علاقـة إيبابيـة بـين أتبـاع الأديـان، مـن شـأهما أن تسـتوعب آفـاق الـروح الإنسـانية وطموحاهــا. فـالنظرة العلميـة الموضـوعية لدراسـة الأديـان تسـهم في تأسـيس قواعـد ومبـادئ مشـتركة تقـرّب بـين آراء الدارسين، في حين أنَّ النظرة غير الموضوعية تزيد الهوَّة والاختلاف بينهم. فالأديان تمثل

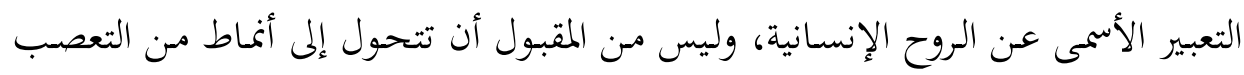
والإقصاء والتحيُّز بتحاه الآخر .

وعندما تكون الدراسة الموضوعية للأديان علماً يبحـث في الإنسان مـن حيـث هو

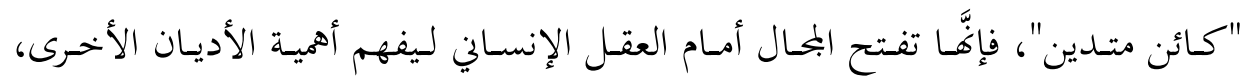

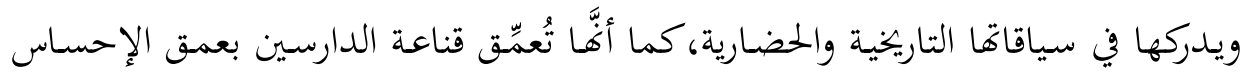
الديني في التاريخ الإنساني، وتختبر المضمون المعرفي للدين مسن حيـث هو فكرة توحيدية وإصالاحية جامعة.

إن الإيمـان القـويم يلهـم العقـل الموضـوعي، وينسير لـه طريـق الرشـاد في خضـم سعيه

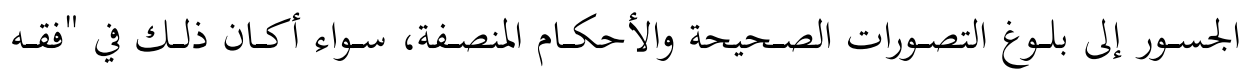

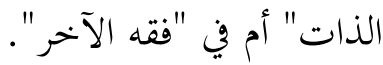

" أستاذ الأديان المقارنة المساعد، جامعة آل البيت، الأردن، البريد الإلكتووني: alhafy30@yahoo.com 


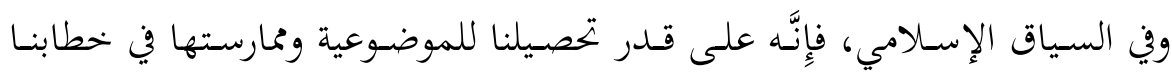

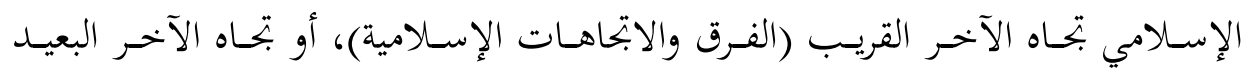

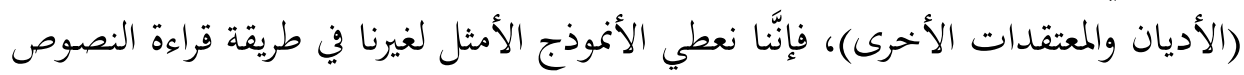
والمعتقدات الإسلامية.

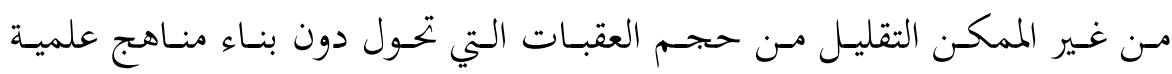

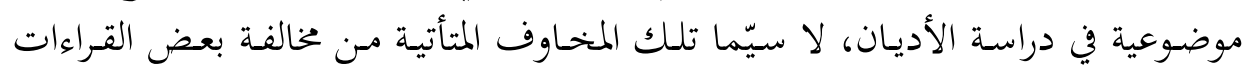

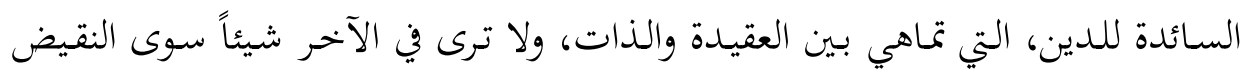

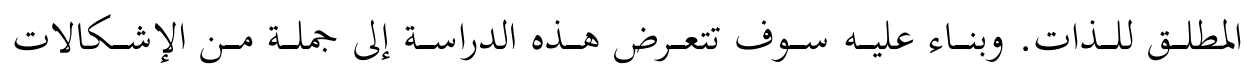

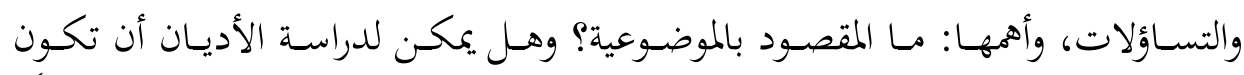

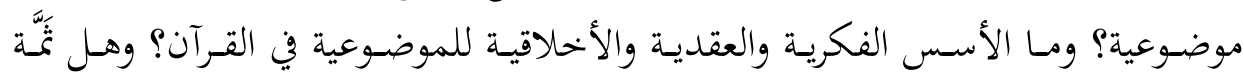

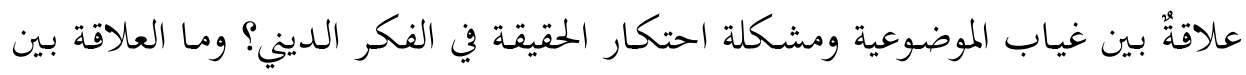

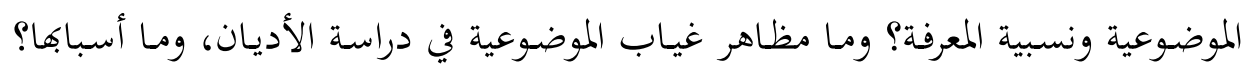

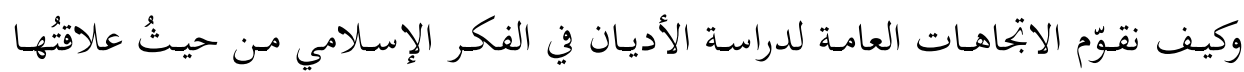

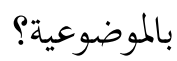

المبحث الأول: مفهوم الموضوعية وإمكانيتها في دراسة الأديان

المطلب الأول: مفهوم الموضوعية:

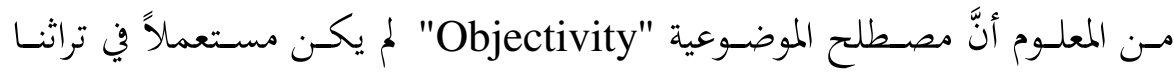

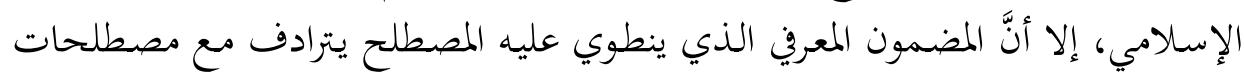

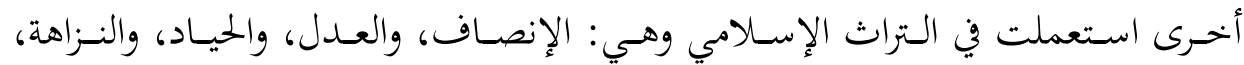

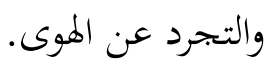

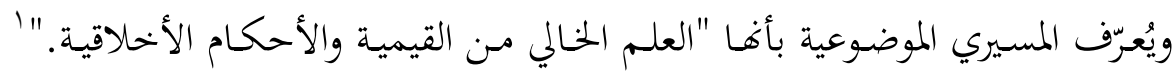

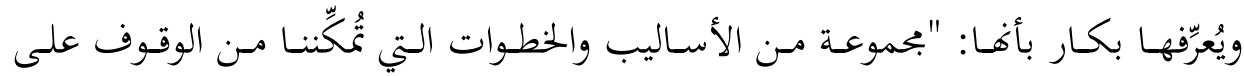

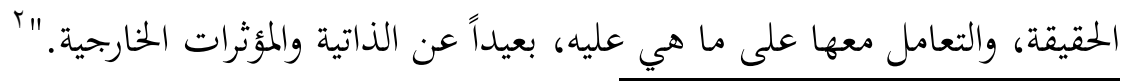

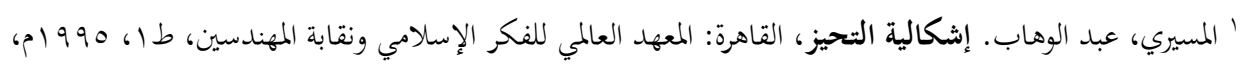

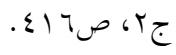


ومسن خـلال النظـر في التعريفـات السـابقة يمكـن اسـتخلاص العناصـر الأساسـية للتعريفات السابقة في النقاط الآتية:

أولاً: المطابقـة للواقع، والمقصسود بها: أن تكشف وتطابق القضية المعرفية مـا يكصل خارج الذهن. ويشير المسيري إلى هذا المعنى بقوله: "إن للموضوعات المعرفية وجوداً مادياً

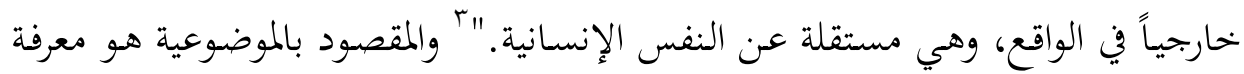
الشيء كما هو عليه بالواقع، دون أن يكون لثقافة الباحث الخاصة وأحكامه المسبقة أثر في تلك المعرفة.

ثانياً: إمكانية التقويم للجميع، فالحقائق التي يثبتها العالِم قد تَحَهَّة الوصول إليها بطريقة تتـاح محاكمتها، والتـدقيق في مـنهج تحصيلها. وفي هذا المعنى يقول المسـيري: "إن العقل يستطيع أن يصل إلى إدراك الحقيقة، وإن الإحكام الموضوعية تستند إلى العقل. "اء ثالثاً: البعد عن الأحكام القيمية والإيديولوجية، أي أنَّ المنهج الموضوعي لا ينبغي

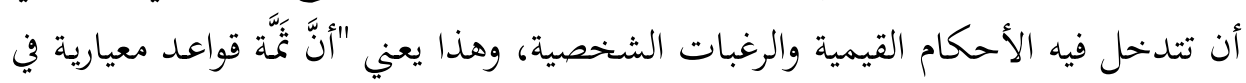

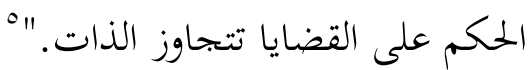

والموضـوعية عمليـة بحثيـة، ومراجعـة نقديـة متواصـلة، تعيـــ النظـر في بحمـل معارفنـا

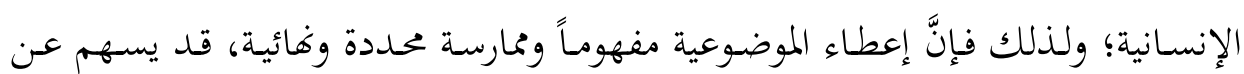

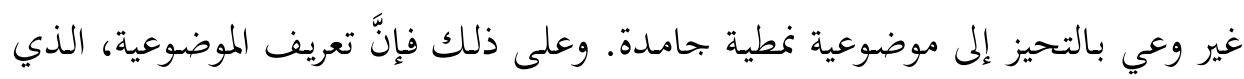

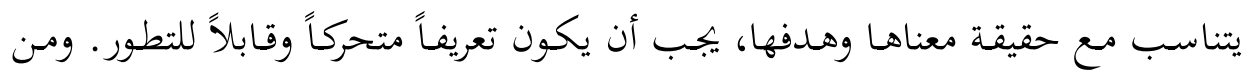

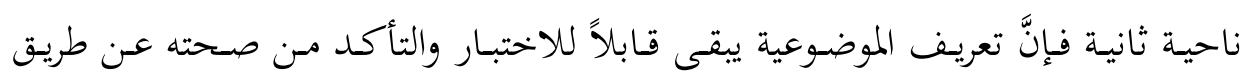
إعادة اكتشاف الحقيقة، من خلال العديد من الباحثين، والتوصل لاتفاق جماعي حول هذه المقيقة.

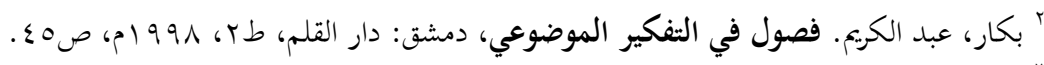

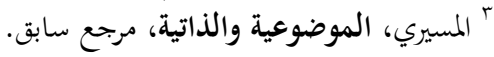

$$
\begin{aligned}
& \text { " المرجع السابق. } \\
& \text { • المرجع السابق. } \\
& \text { † المسيري، إنكالية التحيز، مرجع سابق، جr، صل الــ. }
\end{aligned}
$$


والموضوعية هي عدم التحيّز، والمقصود بالتحيّز "بحموعة من القيم الكامنة المستترة

في النماذج المعرفية والوسائل والمناهج البحثية التي توجه الباحث دون أن يشعر بها، وإنْ شعر بها وجدها لصيقة بالمنهج لدرجة يصعب معه التخلص منها."V" فالموضوعية تقتضي

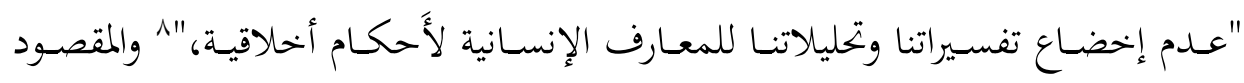
بالأحكام الأخحلاقية هنـا هو : تلك الانفعالات العاطفية والانطباعات المسبقة التي تؤثر سلباً في عملية المعرفة، ولا تعني الموضـوعية أن يتخلى الباحـث عن الأخهاق الإيجابية، كالإنصاف والنزاهة العلمية والعـل والتواضع واحترام الآخـر وحسن الظن به وافتراض الخـير والحكمـة فيسه، بـل إنَّ هـذه الأخهاق هي بمثابـة ضـمانات ضـرورية لبلون المعـارف

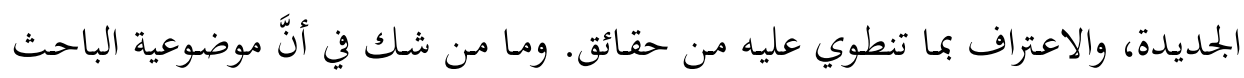
تتـأثر -بمفهومها وتطبيقاتها- بالحقل المعرفي الذي يقوم الباحـث بدراسته، فعندما تتعلق الدراسة بالعلوم الطبيعية والتطبيقية، فإنَّ نطاق التحيّز ونوعه يختلف عنه في دراسة الأَديان والمعارف الإنسانية.

والموضوعية في دراسة الأديان ليست أداة علمية تسهم في توصل الباحث إلى نتائج صحيحة فحسب، بل إنَّ الموضوعية تتجاوز ذلك إلى وعي الذات وفقه الآخر . وتزداد

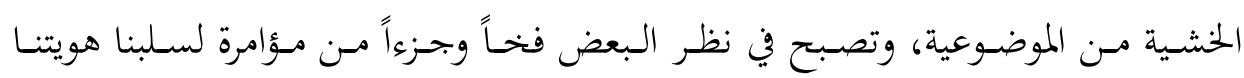

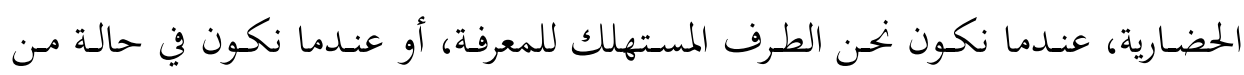
التراجع الحضاري.

\section{المطلب الثاني: إمكانية الموضوعية في العلوم الإنسانية والاجتماعية}

قـد يبـدو الحـديث عن الموضـوعية في دراسـة الأديـان ضرباً مـن المثالية عندما تكـون

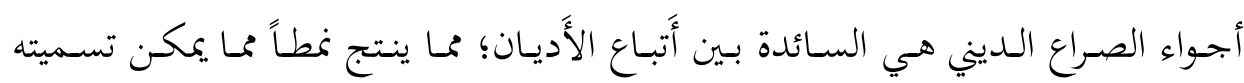

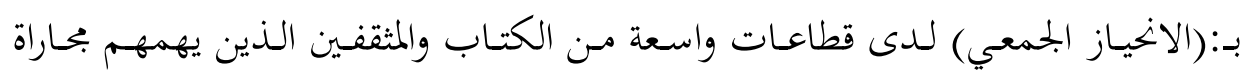


الإحساس العام، والرغبة في تأكيد القناعة السائدة أكثر من انشغالمم باستقصاء المعرفة الموضوعية النزيهة.

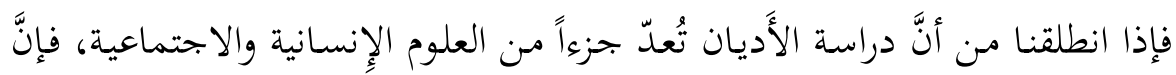

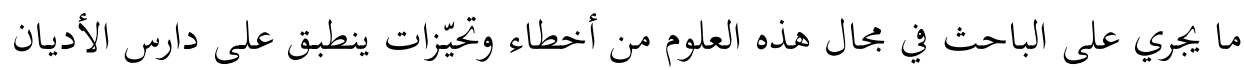

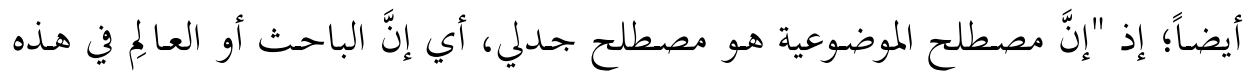

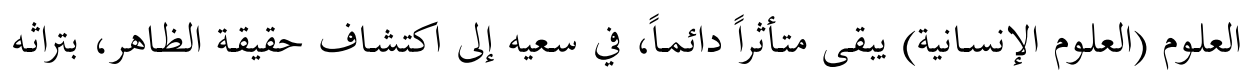

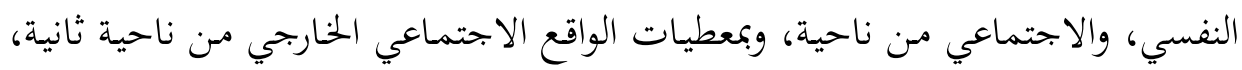

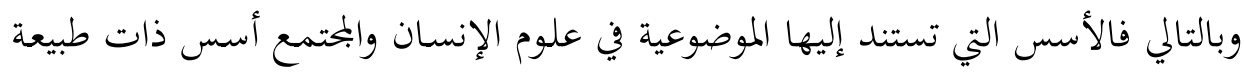
مزدوجة." فوكون الموضوعية ذات طبيعة مزدوجة، لا يعني استحالة السعي إلى تحقيقها،

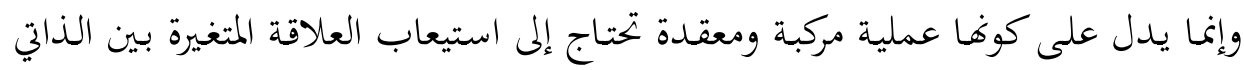
والموضوعي.

وهناك مـ يذهب إلى أنَّ الموضوعية في دراسة العلوم الاجتماعية متحيّزة بطبيعتها،

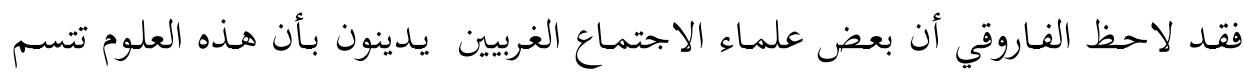

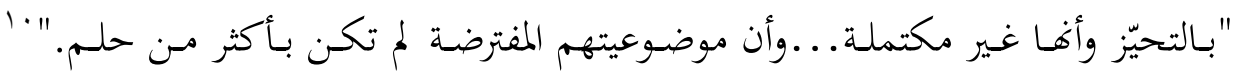

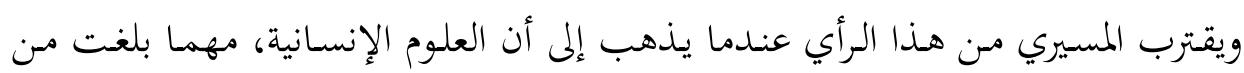

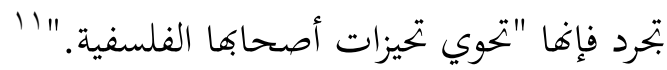

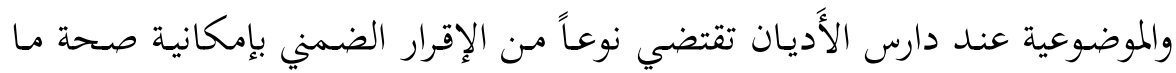

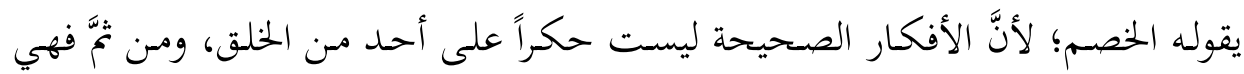

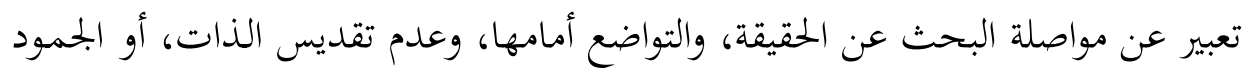

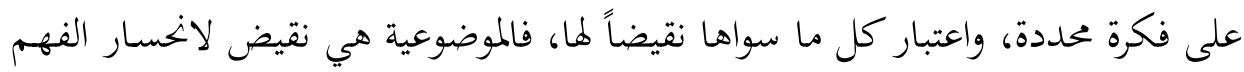
والتفكير المحدود.

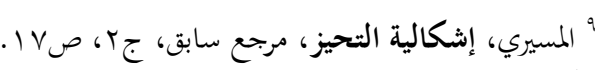

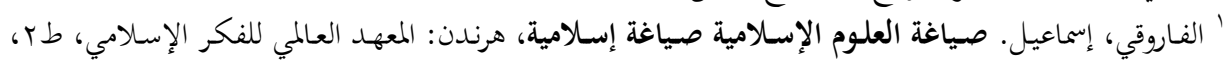


إنّ عدم تحقيق التجرد المطلق عن كل تحيُّز وعصبية عند بعض دارسي الأديان، لا يعني عدم تحقيق ما يمكن تحقيقه من الموضوعية، فالموضوعية شأفا كشأن المثل الإنسانية

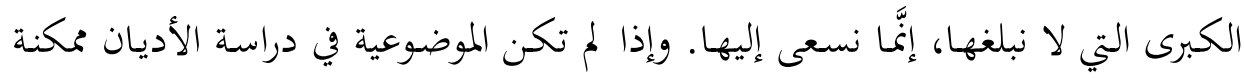

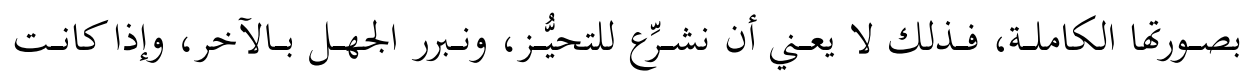

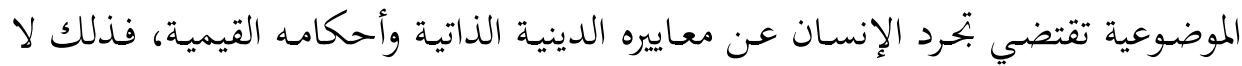
يعني رفض القيم بحد ذاتما، أو التخلي عن عقيدته الدينية.

\section{المبحث الثاني: أسس الموضوعية في القرآن الكريم:}

\section{المطلب الأول: الأسس العقدية والفكرية للموضوعية في القرآن الكريم}

تقوم الموضوعية في القرآن الكريم على جملة مـن الأسس العقدية والفكرية، با ومن جملة هذه الأسس:

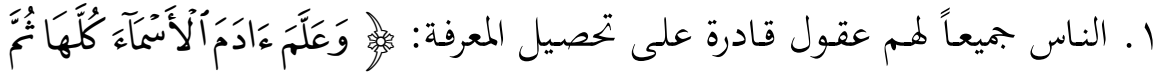

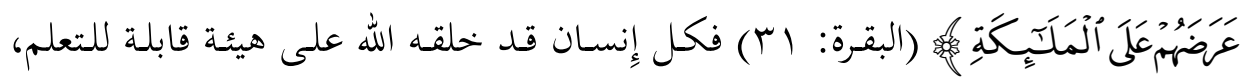
وهذه السِمة هي التي امتاز بها آدم من سائر الخلق، واستحق من أجلها سجود الملائكة.

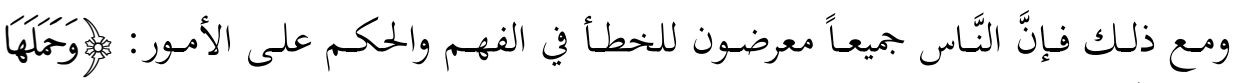

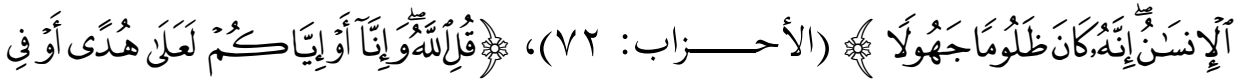

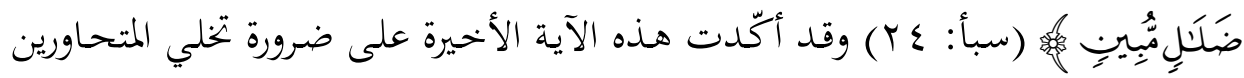

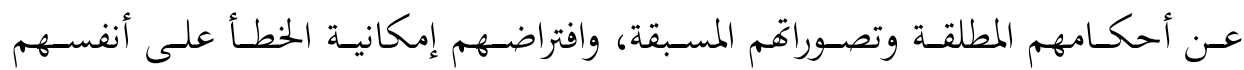
وإمكانيـة الصـواب على غيرهم، فمسـاواة الآخـر بالذات أمـام البحـث عن الحقيقـة هـو الذي يؤسس للقراءة الموضوعية للآخر.

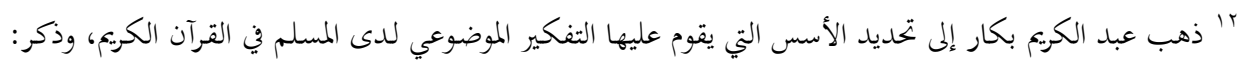

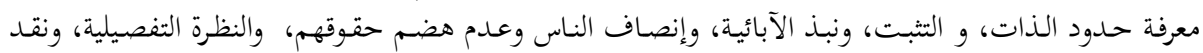
الذات، والمرونة الذهنية. انظر:

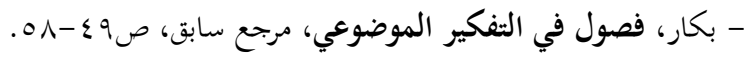


r. خَلَق اللهُ الناسَ مختلفين بالجنس أو العرق أو الدين بغرض التعارف فيما بينهم.

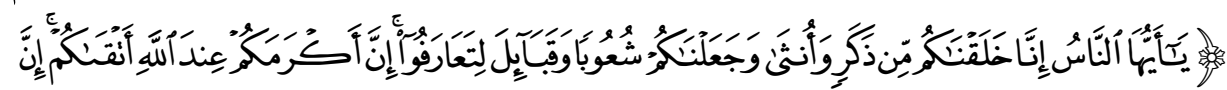

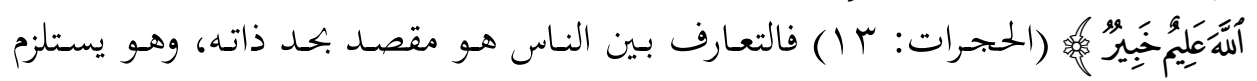
العدل والإنصاف في دراسة الآخر في كل أبعاده وجوانبه الدينية والثقافية والحضارية.

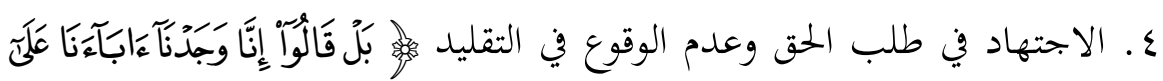

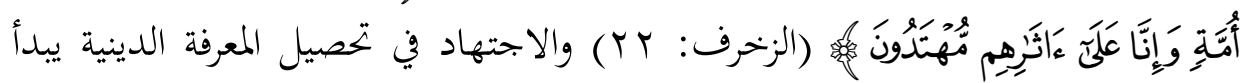

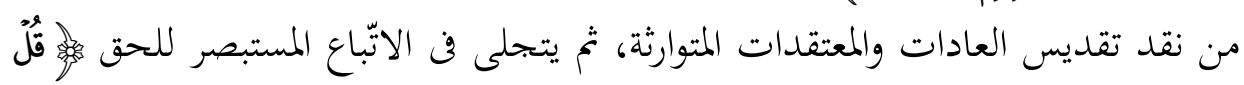

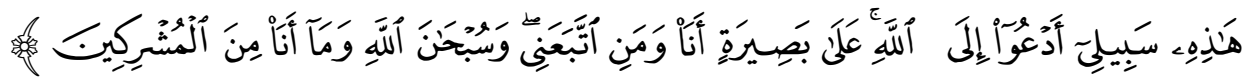

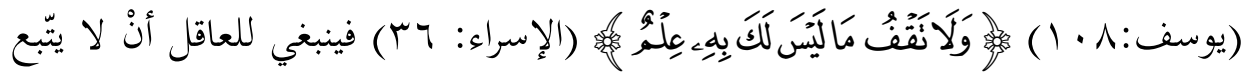
ما لا يعرف، سواءً أكان ذلك في مجال الأفكار والمعتقدات الدينية أم الدنيوية، والمستغرب دوماً عند عموم الحكماء، كيف يحرص عموم الناس على بذل جل طول طاقتهم في تحصيل المعارف التي تُصْلِح هُم معيشتهم الدنيوية، ولا يبذلون جهدهم واجتهادهم في تحصيل المعارف الدينية التي تصلح حياقم وآخرقم.

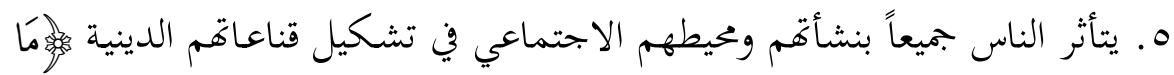

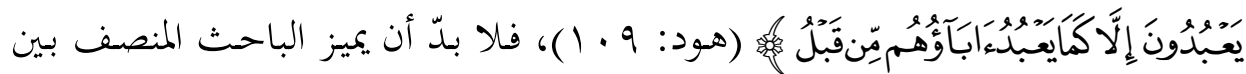

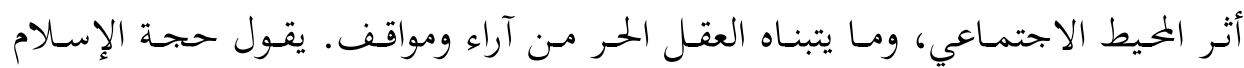

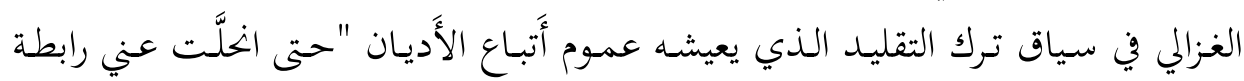
التقليد، وانكسرت علي العقائد الموروثة، على قرب عهد في سن الصبا؛ إذ رأيت صبيان

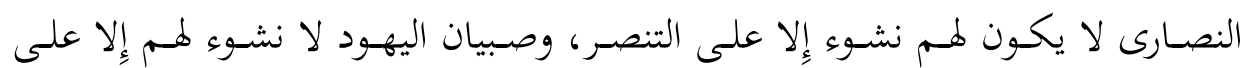

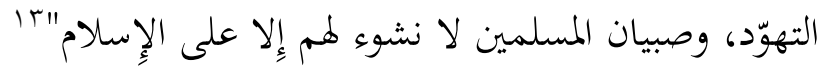

ج. الناس جميعاً من أي دين كانوا مدعوون إلى النظر والتفكر والتدبر، واستعمال الأدلة البرهانية، وهذا يؤكد اهتمام القرآن بالمعرفة العلمية الموضوعية كما في قوله تعالى:

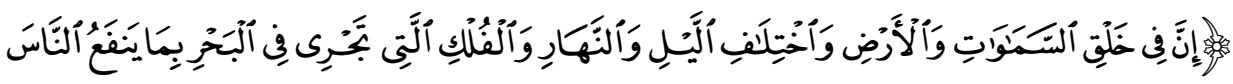




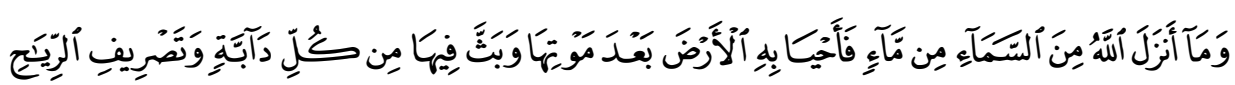

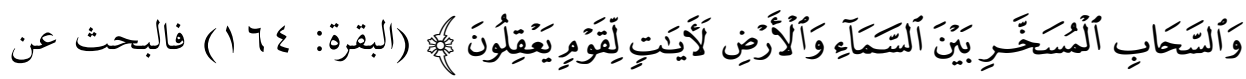

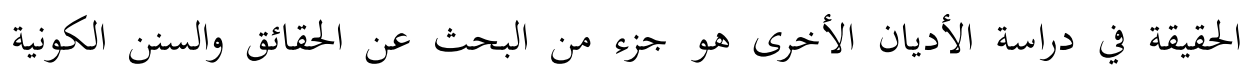

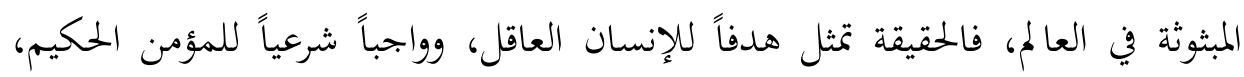
وينبغي لمن يقرأ القرآن قراءة عميقة أن لا يختزل الحقائق فيما بين يديه دون أن يسعى إلى اكتساب معارف جديدة.

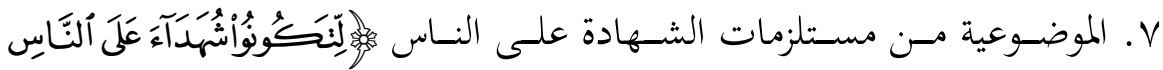

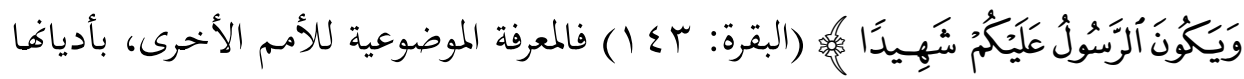

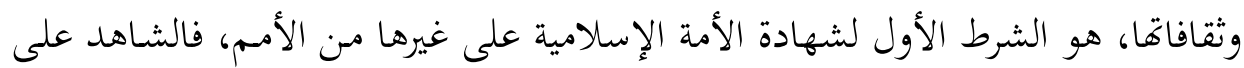

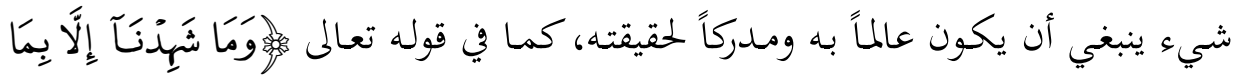

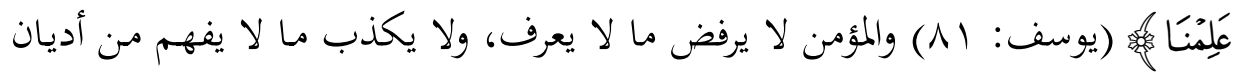
الآخرين؛ لأنه إن فعل ذلك لغيره فإنه يبيح لهم فعل الشيء ذاته بتحاه الإسام؛ ولذهلك

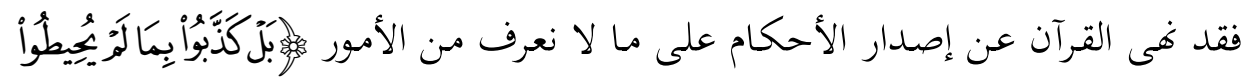

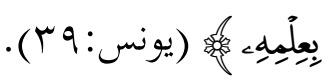

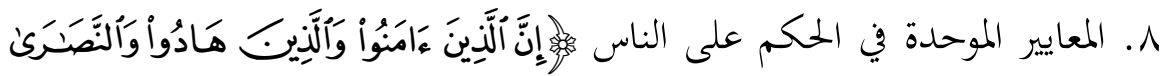

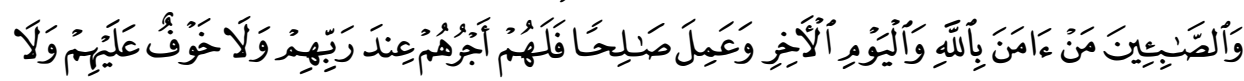
هُمْ يَّرَنُوَتِ

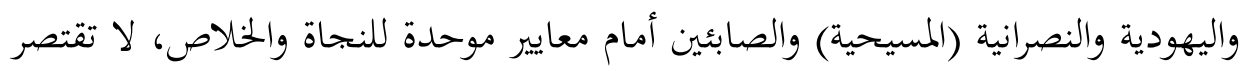
على اسم دين بعينه، وكلّ من استوفى هذه المضامين الدينية الجوهرية (وهي الإيمان بالله واليوم الآخر والعمل الصالح)، لا خوف عليه في العدالة الإلهية المطلقة. ومن الآيات التي

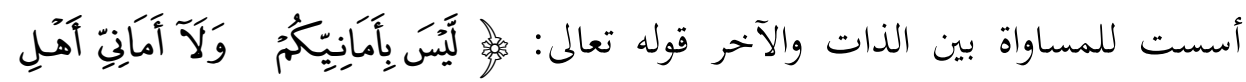

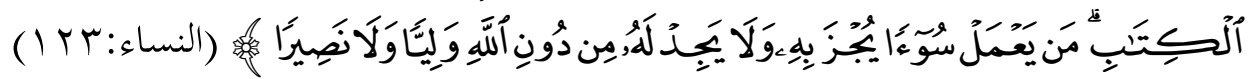
فلا محاباة ولا تحيز لفئة من الخلق دون غيرهم. فحقائق الأعمال، وليس أوهام الأماني، هي التي عليها التعويل في بلوغ الحق وتحصيل السعادة. 
وعندما ننطلق من الحديث الذي رواه أنس بن مالك عن رسول الله -صلى الله عليه

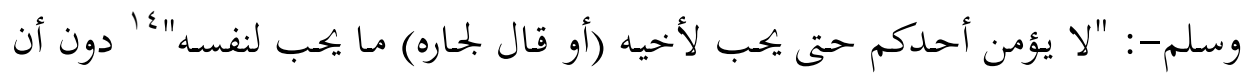

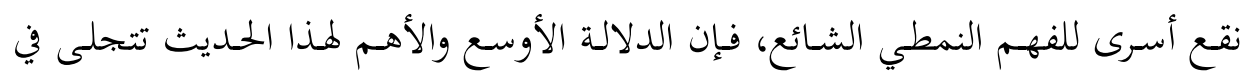

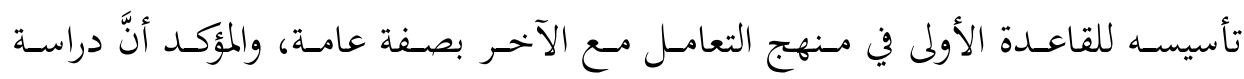

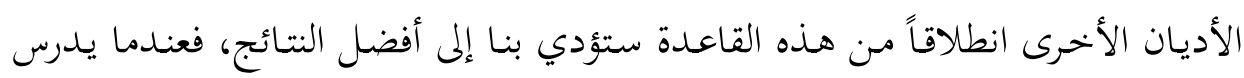
البوذي الهندوسية بالطريقة التي يدرس بها الهندوسي ديانته، وعندما يدرس المسلم الأديان

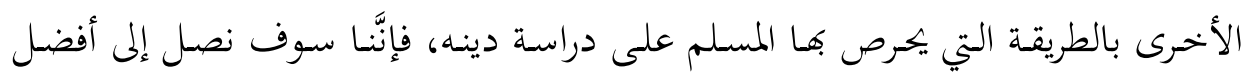
معرفة ممكنة للآخر.

أمـا إذا كنـا نلوم الآخحرين على بتحاوزهم للموضوعية وانحيازهم لأفكارهم المسبقة ثم

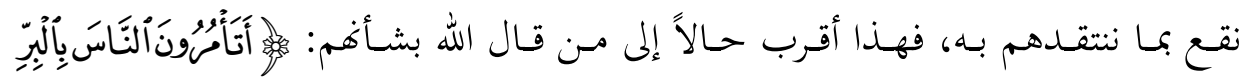

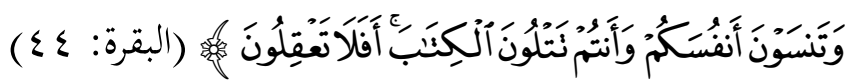

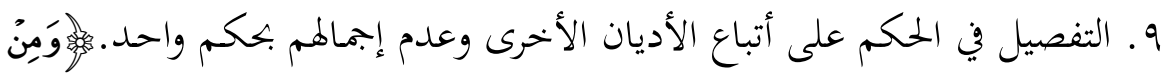

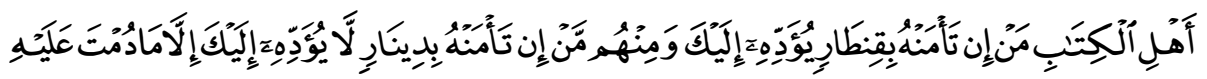

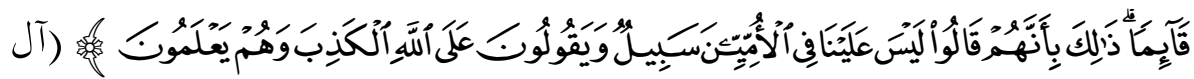

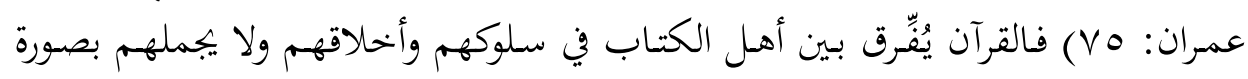
واحدة:

\section{المطلب الثاني: الأسس الأخلاقية للموضوعية في القرآن}

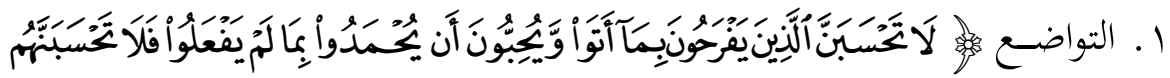

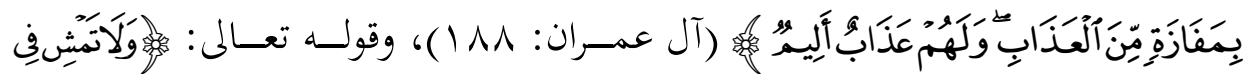

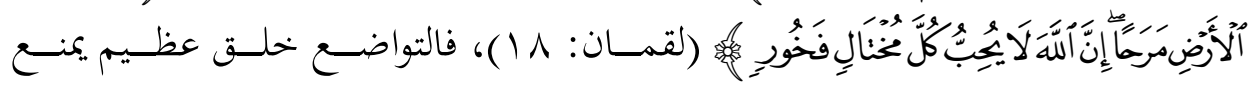

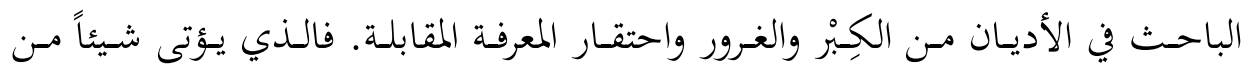

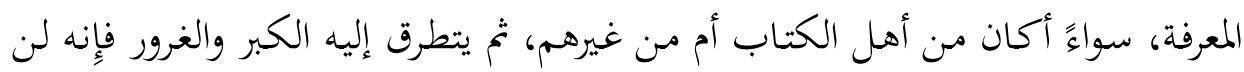
يتمكن من إدراك أخطائهِ وإخفاقاته، وسوف ينتهي به المطاف إلى الجهل والهلاك. ؛' مسلم بن الحجاج. صحيح مسلم بشرح النووي، بيروت: دار إحياء التراث العربي، جr، صل ا. 
وإذا كان خطاب القرآن لأفضل الخلق وأعلمهم بالدين بأن يسعى إلى الاستزادة في

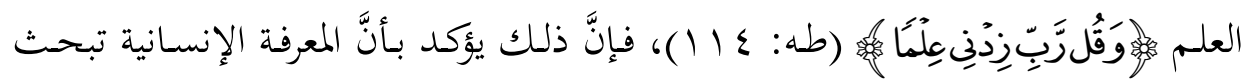

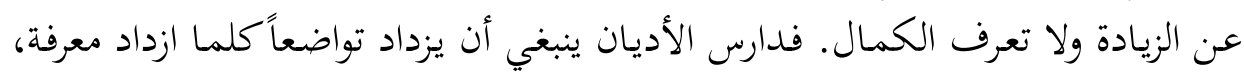
خلافاً للدارس المنحاز والمتعصب الذي يقف عند عند ما أوتيه، ويظنه فهاية المراد.

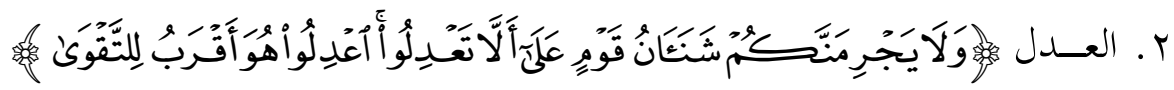

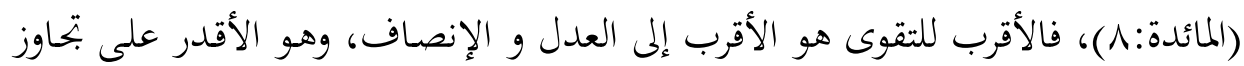

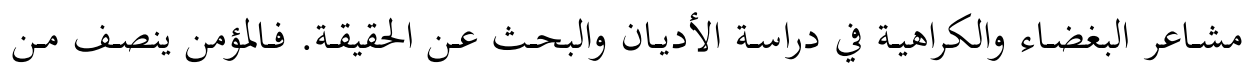

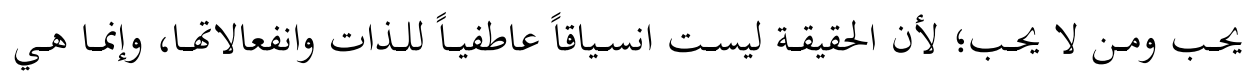
تجاوزٌ لتلك الذات وتحييدٌٌ لتلك الانفعالات، فالذي يؤدي بالإنسان إلى الخطأ وإنكار

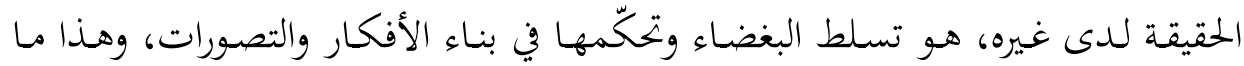

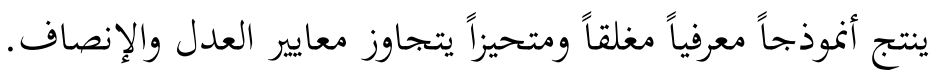

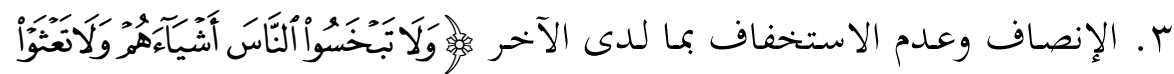

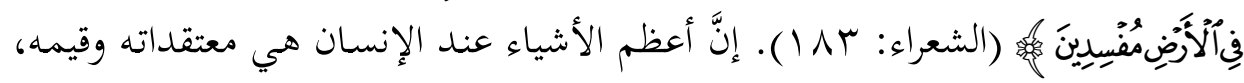

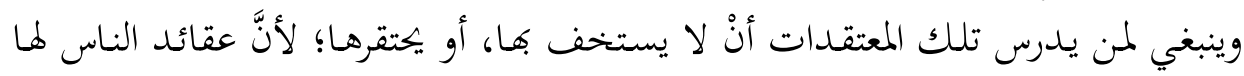
مكانـة في قلوب أتباعها تضـاهي تلـك المكانـة التي في قلـب الباحـث المسـلم بحـاه دينـه

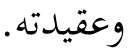

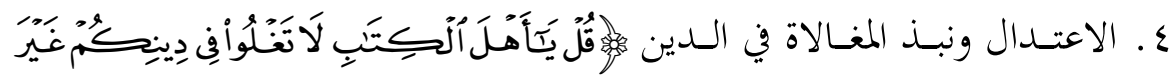

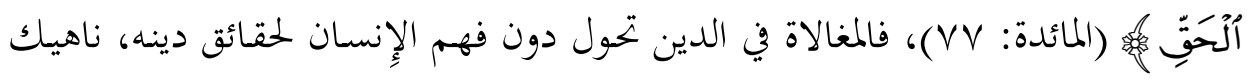
عن فهمه لديانة غيره. والواقع التاريخي يشهد أن الغلو في الدين كان أحد أبرز أسباب

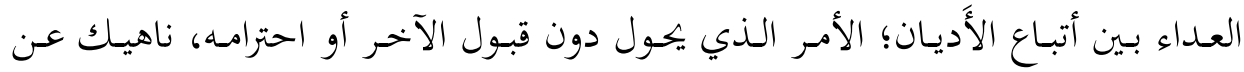
فهمده وإنصافه.

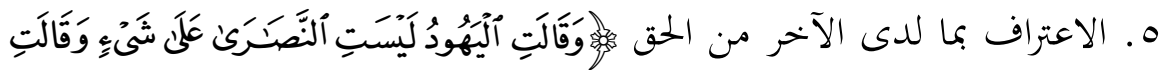

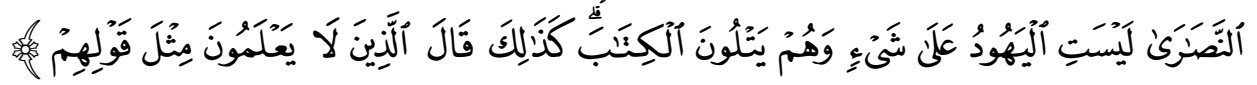

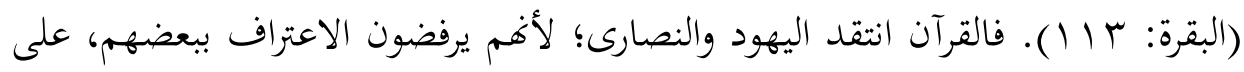


الرغم من الأسس المشتركة التي تحمع بينهم، وهذا يعني أن أتباع الأديان ينبغي عليهم

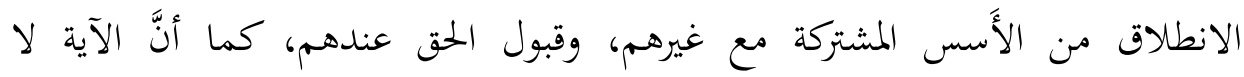

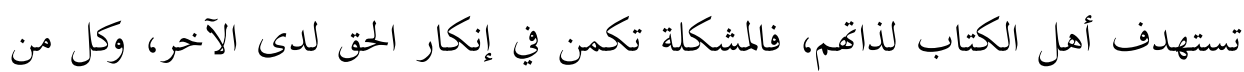

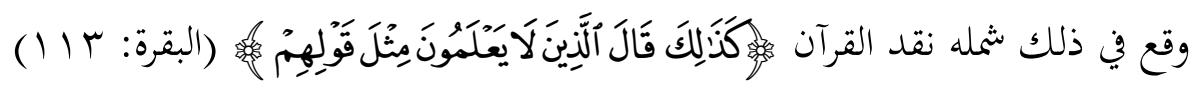

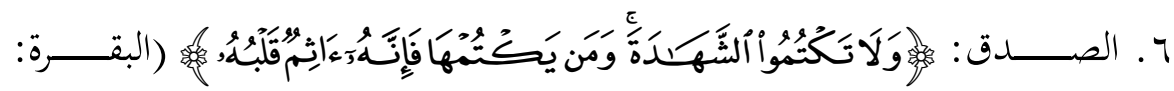

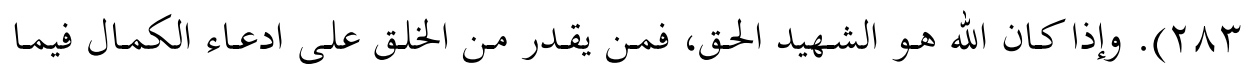

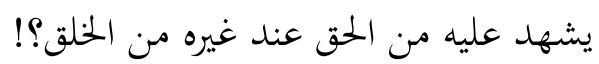

المبحث الثالث: الموضوعية واتجاهات دراسة الأديان في الفكر الإسلامي المطلب الأول: اتجاهات دراسة الأديان في الفكر الإسلامي تختتلف الدراسـات الإسـلامية في دراسـة الأديـان مـن حيـث قربهـا أو بعـدها مـن

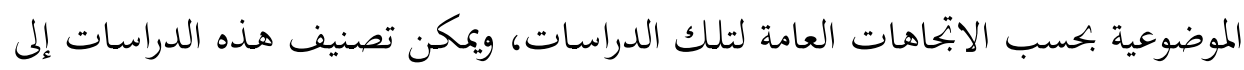

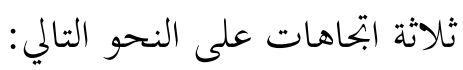
أولاً: الكتابات النقدية والجدلية.

وهي أكثر الكتب التي ألفت في الملل والنّحل، ومن أبرز هذه الكتابات: الفِبوصَل

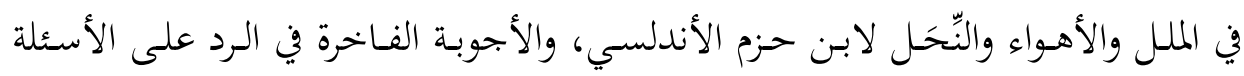
الفاجرة للقرافي، وهداية الحيارى لابن قيم الجوزية.

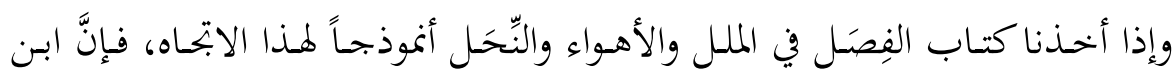

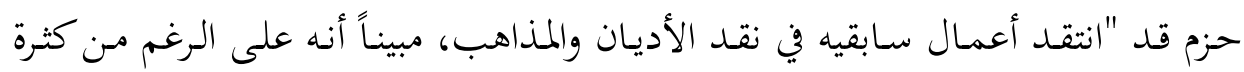
التأليف في هذا البحال، فإن النزر اليسير منه فقط قد التمال اتبع الطريقة السوية في النقد."

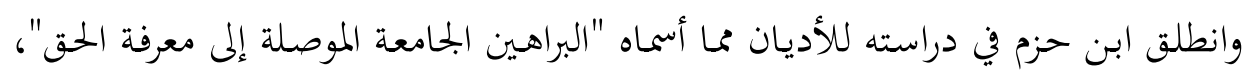

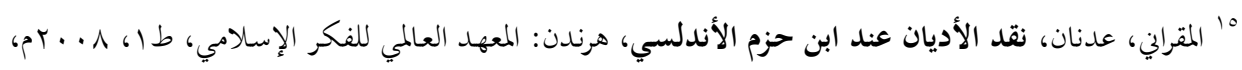


وهي براهين منطقية تقوم على معطيات الحواس الخمس، وأولويات العقل وبدهياته، وقد

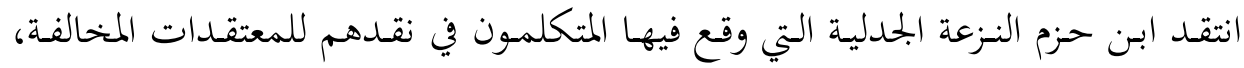
ورأى أنَّ الجدل وحده دون برهان يبين الصواب، إنما هو شغب لا طائل منه. 17

\section{ثانياً: الكتابات الوصفية والتحليلية.}

وهي تُعنى ببسط الآراء والمعتقـدات أكثر مـن اهتمامها بنقـدها وتقويض أسسها،

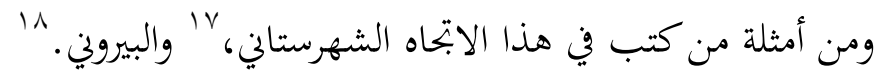
وإذا أخـذنا كتـاب البيروني أنموذجـاً لهذا الاتجـاه، فيمكننـا بداية تصـنيفه ضسمن علم تاريخ الأديان أكثر من كونه في علم مقارنة الأديان، ويتسم هذا الكتاب بأنَّهَ وَصَفَ لنا معتقدات المنود كما هي، فالبيروين في أخباره عن الأديان، لم يناقض الخصوم، ولم يتحرج

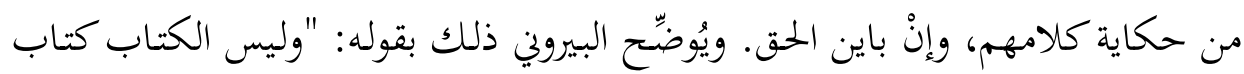

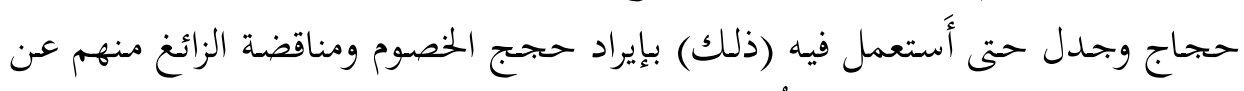

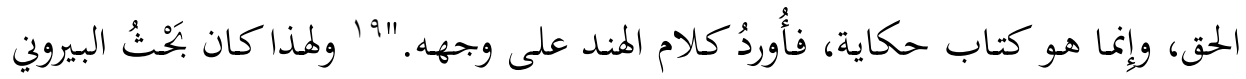

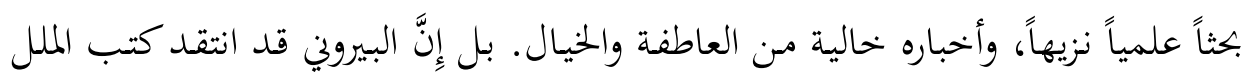

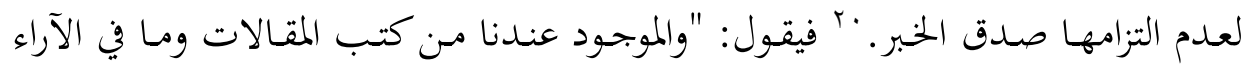
والديانات لا يشتمل إلا على مثله، فمن لم يعرف حقيقة الحال فيها اغترف منها ما لا لا لمان

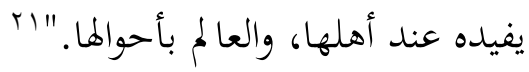

إنَّ ما يميز البيروني،، أنَّه يفكر بوصفِه إنساناً يبحث عن المعرفة بنفسه، وبوصِفهِ مقرِرًاً أو مُفسِّراً لعقائد مسبقة، وهـذا ينـدر وجـوده عنـد كثير مـن دارسي الأديـان المعاصرين.

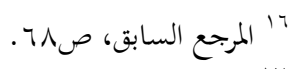

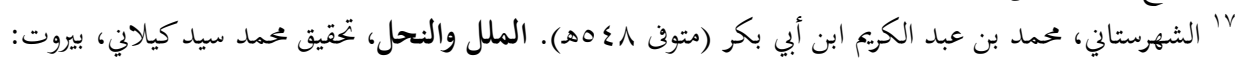

دار المعرفة، ع. ــ اهـ

^’ البيروني، أبو الريحان محمد بن أحمد.تحقيق ما للهند من مقولة مقبولة في العقل أو مرذولة، بيروت: عالم الكتب،

طب، بما9 ام.

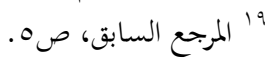

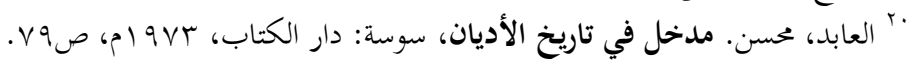

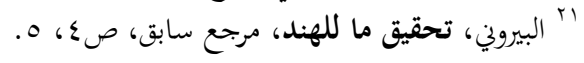


وتتجلى موضوعية البيروني في كتابة (تحقيق ما للهند) من خلال السمات الآتية: إتقانه

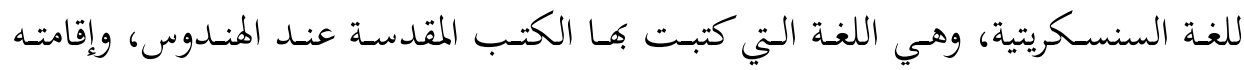
الطويلة في الهند وعلاقته المباشرة مع موضوع دراسته، ومعرفته ودراسته للفلسفة، فتبنه فتكوينه

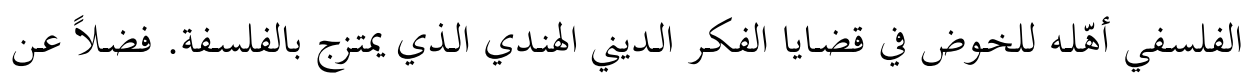

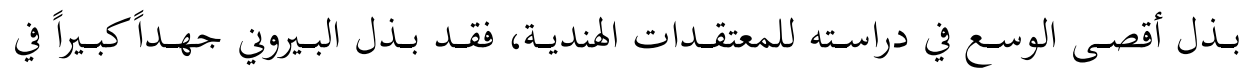

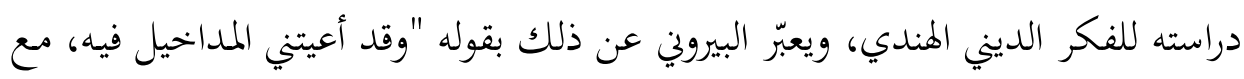

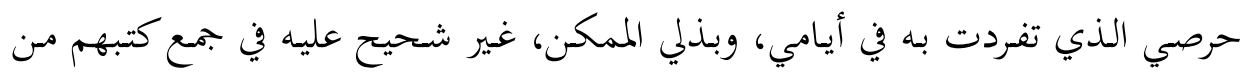

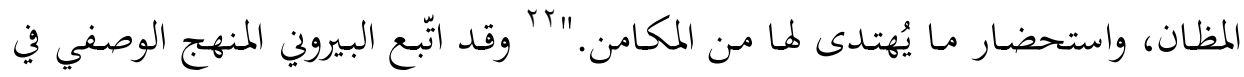

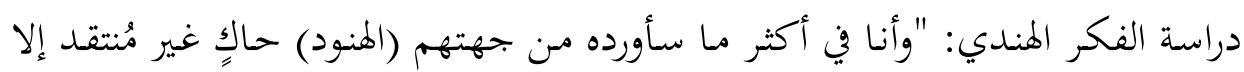

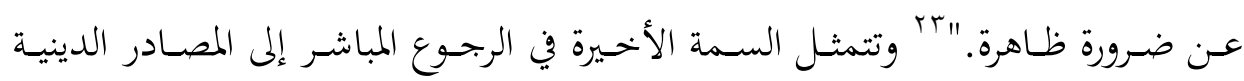

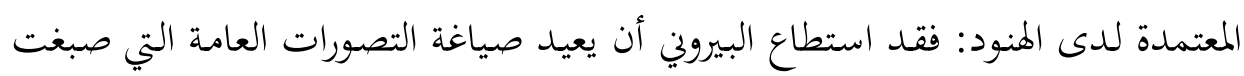

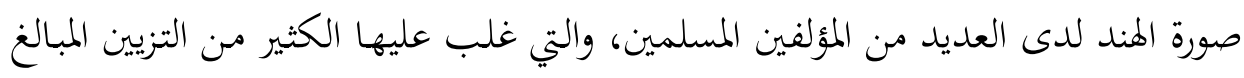

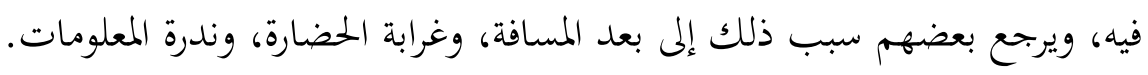

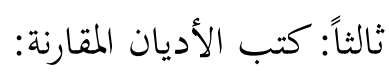

أبرز الكتب وأكثرها تطوراً في دراسة الأديان المقارنة في التراث الإسلامي القديم هو

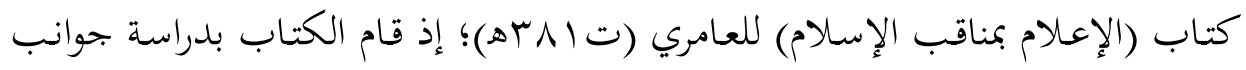

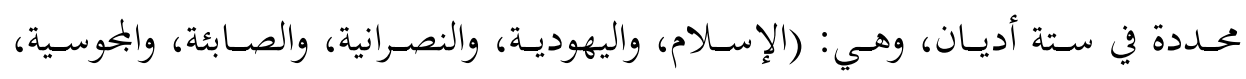

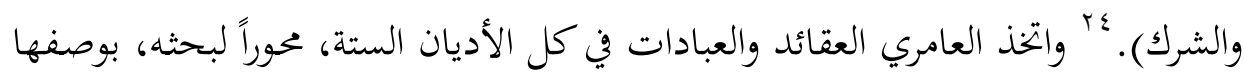

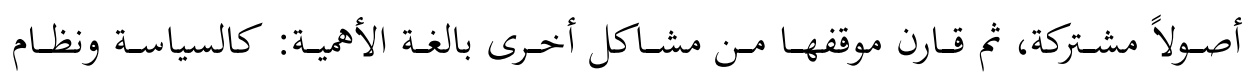

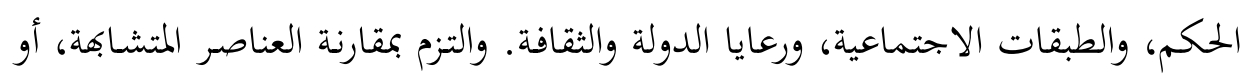

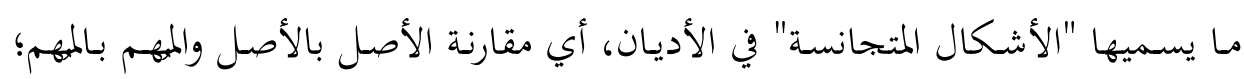

$$
\begin{aligned}
& \text { rr المرجع السابق، ص1/1. }
\end{aligned}
$$

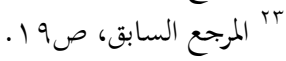

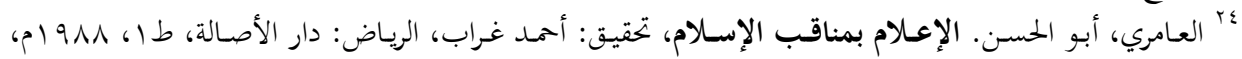


إذ من الخطأ وعدم الإنصاف مقارنة الأصل بالفرع، أو مقارنة جانب مهم في دين بجانب أقل أهمية في دين آخر. وفي ذلك يـذكر: "وقبـل أن نشرع فيما وعـدناه مـ مقابلة ركن بركن مما يترتب تحت الملة الحنيفية بنظيره من المرتب تحت الأديان الأخرى، يجبب أن نقدم مقدمة فنقول: إن تبيان فضيلة الشيء على الشيء بحسب المقابلات بينهما قد يكون صواباً وقد يكون خطأ. وصُورَر الصواب معلقةٌ بشيئين: أحدهما: ألا يوقع المقايسةً إلا بين الأشكال المتجانسة، أعني ألا يَعْمَد إلى أشرف ما في هذا فيقيسُه بأرذل ما في صاحبه، ويعمد إلى أصل من أصول هذا فيقابله بفرع من فروع ذاك. والآخر : ألا يعمد إلى خلِّة موصوفة في فرقة مـن الفرق، غير مستفيضة في كافتها، فينسبها إلى جملة طبقتها. ومتتى حافظ العاقل في المقابلة بين الأشياء على هذين المعنيين فقد سهل عليه المأخذذ في توفية

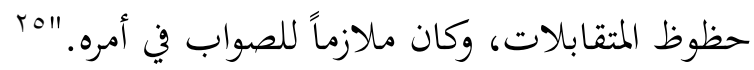

لقـــ التـزم العـامري في مناقشـة كـل ديـن على أسـاس مبادئـه المقبولـة لـدى جمهـور المعتنقين له، كما أنه لم يأخـذ برأي فرقة دينية واحلدة (أو أقليـة) في أي دين، على أهـا تمثل أهل ذلك الدين جميعاً. بr وهذا يختلف كثيراً عن منهج الرازي في كتابه (مناظرة في

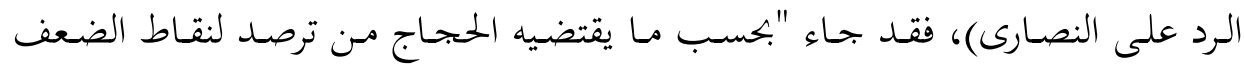

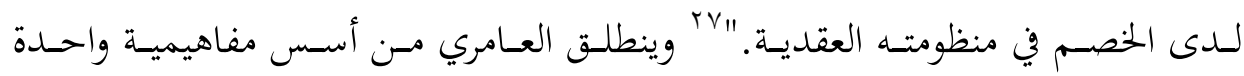
ومشتركة، يتفق عليها العقلاء من أتباع الأديان جميعها، ومن ذلك عرض العقائد، سواء

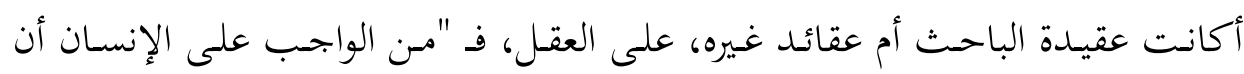
يعرض جميع ما يسنح لقوته المتخيلة من الأبواب الاعتقادية على قوته العاقلة؛ ليأمن بـ إِه

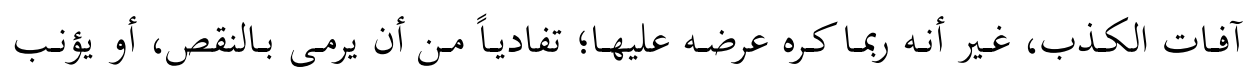

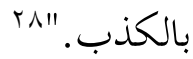

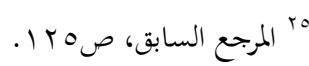

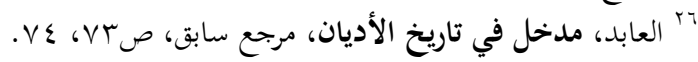

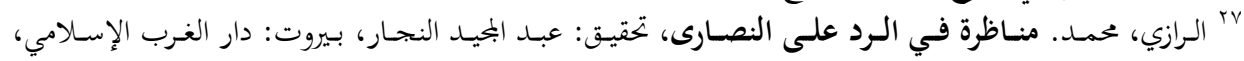


كما انتقد العامري التقليد في البحث العلمي في مسائل العقائد والإيمان على العلى

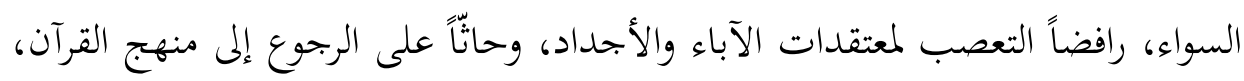

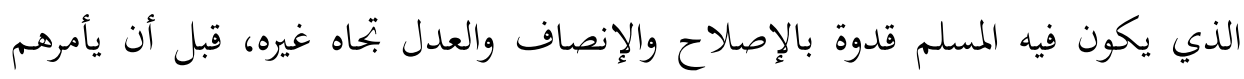

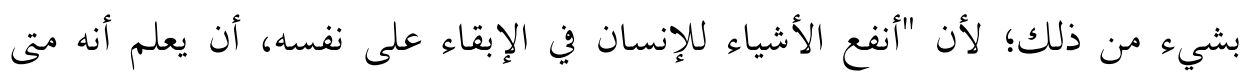

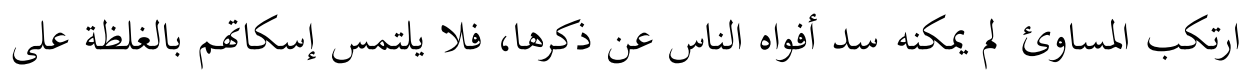

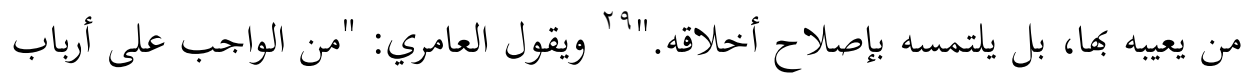

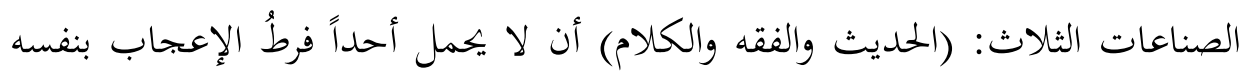

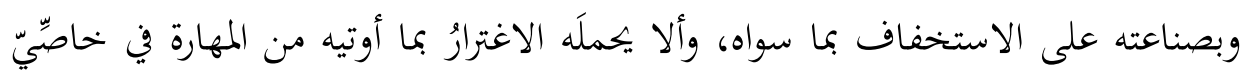

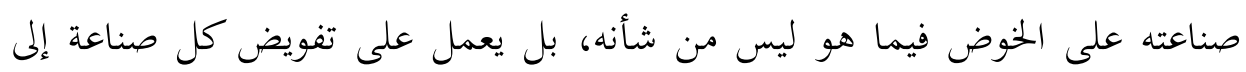

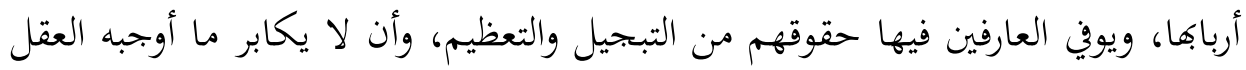

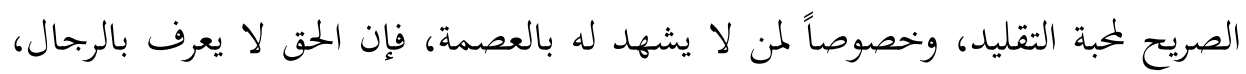

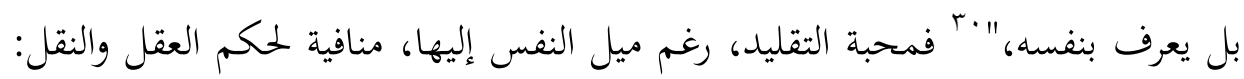

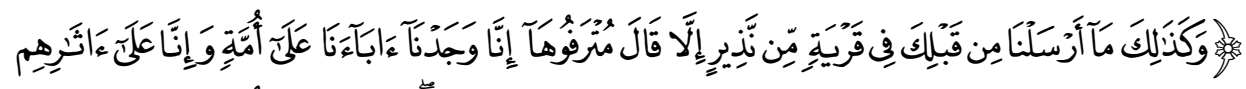

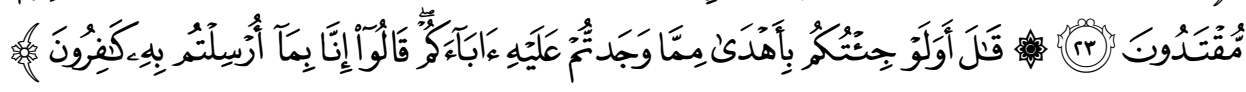

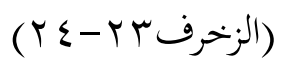

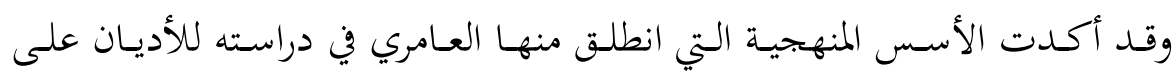

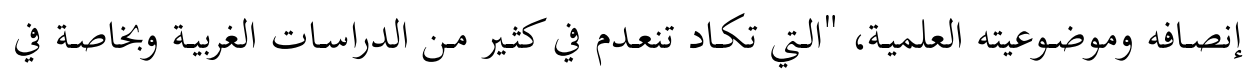

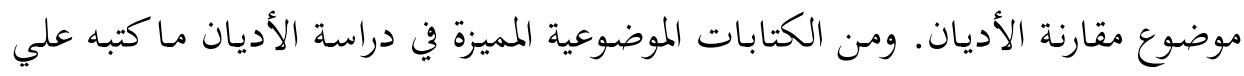

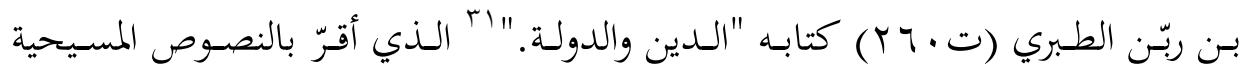

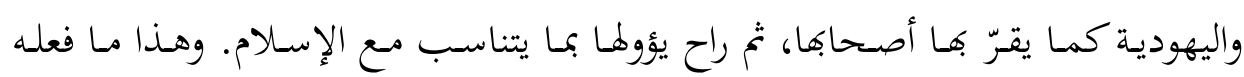
الغزالي في كتابه (الرد الجميل).

$$
\begin{aligned}
& \text { "rar }
\end{aligned}
$$

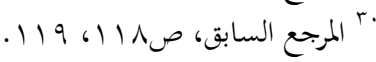

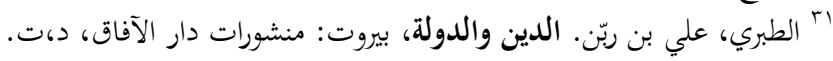

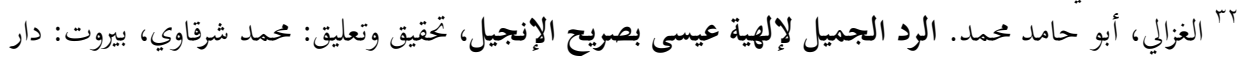


إن كتابات الأديان القديمة كانت وليدة بيئتها وظروفها الاجتماعية والثقافية، وكانت لما إِيجابياهـا العديدة، لكنهه مـن غير المقبول أن تبقى هذه الكتابـات المصدر الوحيد في دراساتنا للأديان الأخرى في العصر الحاضر، فتد تطورت دراسة الأديان بصورة كبيرة في القـرون الثلاثنة الأخهيرة، وذلك بعـد تطور علمم اللغـات والآثـار والأَثنروبولوجيـا، وظهـور المدارس المتعددة في دراسة الأديان، فكم من الأديان التي لم يتطرق إليها الشهرستاني أو ابن حزم أو المسعودي، وكىم مـن المذاهب الجديدة التي ظهرت في الأديان التي درسها علماؤنا القدماء بعد أن أبجزوا كتاباقم. ولعل الطريقة الأسهل في دراسة الأديان والمتمثلة في الرجـوع إلى الصسيغ المنجـزة والجـاهزة في مؤلفاتنـا القديمـة، هي الأبعـد عـن الموضـوعية والنزاهة العلمية، فالمعرفة الإنسانية بالأديان هي معرفة تراكمية (طورية)، لم تولد كاملة، ولن تكون كذلك في يوم من الأيام.

\section{المطلب الثاني:سمات المنهج الموضوعي لدراسة الأديان}

من أبرز السمات التي يتسم بها المنهج الموضوعي لدراسة الأَديان ما يأتي: ا ـ التكاملية المعرفية: ضرورة السعي نحو بنـاء معرفة تستوعب الأدبيـات الحضـارية والفكرية والثقافية المرتبطة بالأديان، حتى تكون الدراسات الدينية أقرب إلى الموضوعية.

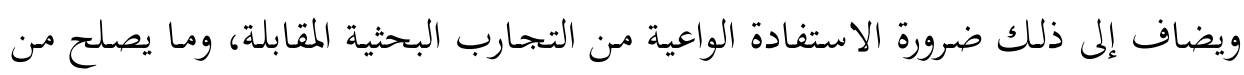
مناهج العلوم الإنسانية. ومن جوانب التامل ضرورة التعرف على التراث الديني الإنساني،

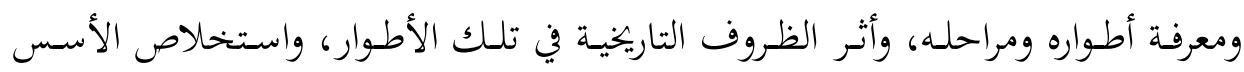

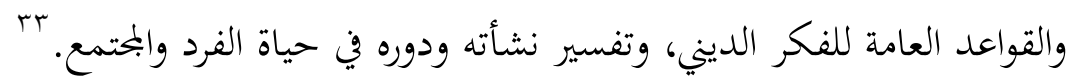
r. النظرة النقدية الشاملة لمعارفنا ومسلماتنا وأفكارنا الدينية حول الآخر، والتعرف على مواطن الضعف والقوة فيها، ومن ذلك ضرورة إعادة النظر في تصنيف الأديان على

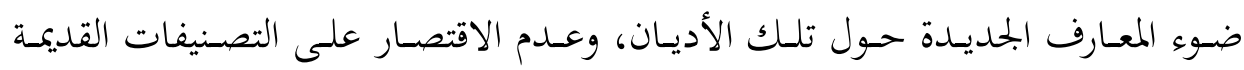
للعلماء السابقين. 
r. دراسة الأديان دراسة مستقلة عن علم الكلام وكتب العقائد؛ لأن عموم هذه ردمان

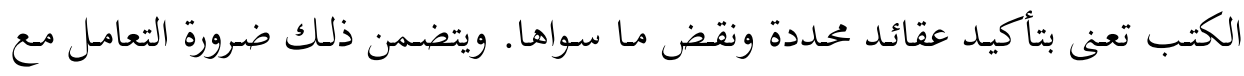

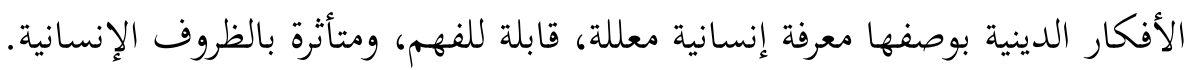

ع. التفريق بين الحكمم النظري على صحة الأديان من جهة، ووظيفتها من جهة

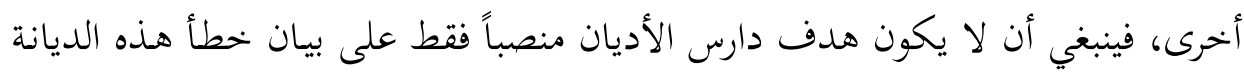

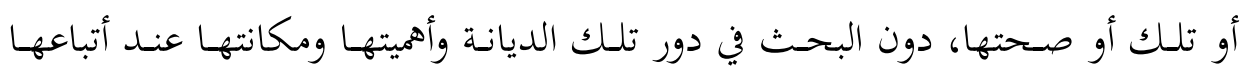

ومعتنقيها.

هـ بتحاوز اختلاف المصطلحات والألفاظ إلى الحقائق والمفاهيم الجوهرية التي تكمن

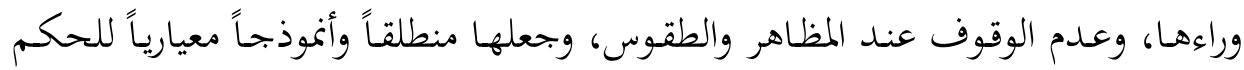

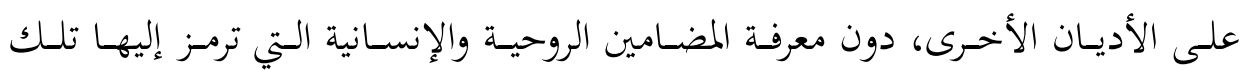
الأشكال والمظاهر.

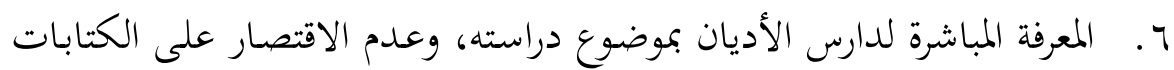
والنصوص للتعرف على التجارب والخبرات الإنسانية التي يعيشها أتباع هذا الدين.

\section{المبحث الرابع: غياب الموضوعية، ومركزية الحقيقة الدينية}

\section{المطلب الأول: الموضوعية واحتكار الحقيقة الدينية}

إن أهم الأسباب التي تحول دون الوصول إلى المعرفة الصحيحة أو الحقائق الموضوعية

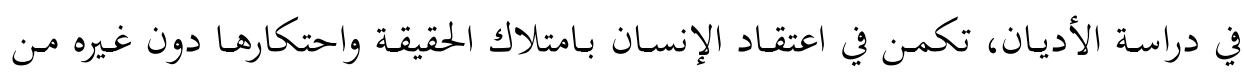

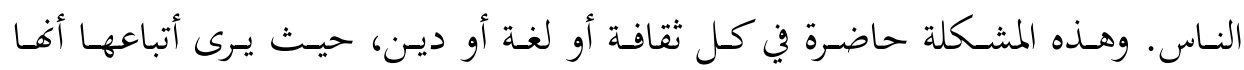
الأنموذج الأكمل الذي ينبغي أن يبقى متفوقاً على غيره.

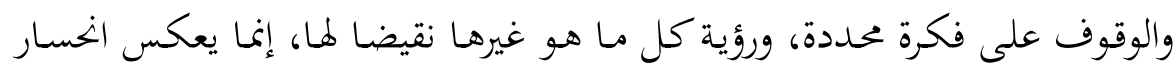

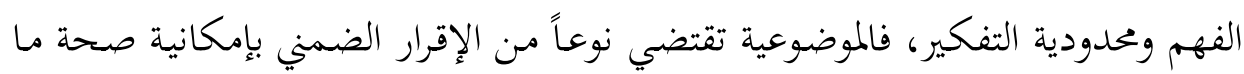

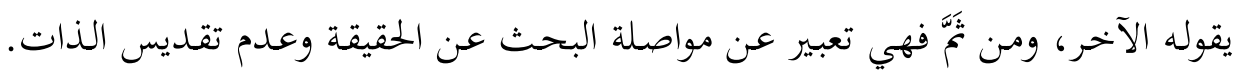


ومفهوم التحيز هـو في جـوهره نوع مـن التمحسور أو التمركز حول (الذات)، والانغلاق

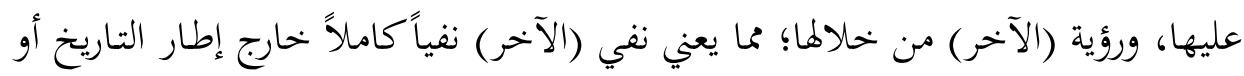

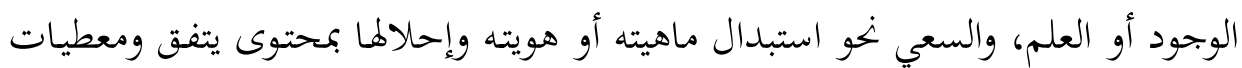

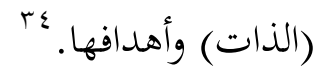

إن مشكلة مركزية الذات تكمن في رؤية (الأنا) مركزاً ومعياراً مطلقاً للحقائق والقيم، ومن هنا يصبح الانحياز في نظرهم للذات هو الخياز للحقيقة، وتغدو المعرفة وجميع أدواتها

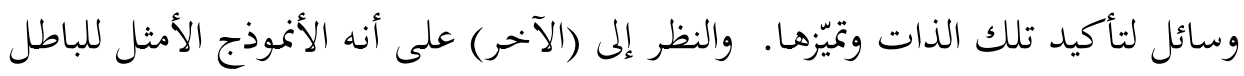

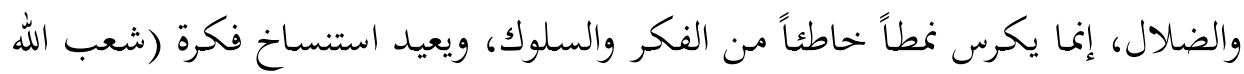

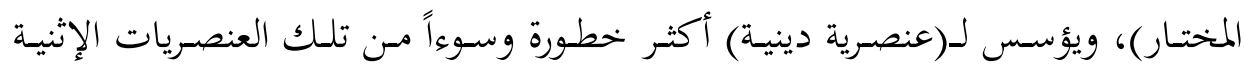
والقومية.

وفي هذا السياق ينتقد القرآن حصر التصديق والصواب باتباع دين محدد دون غيره.

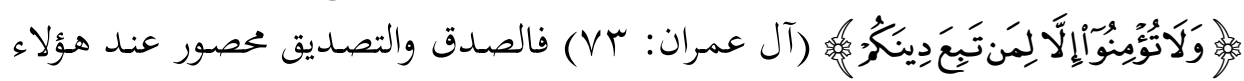

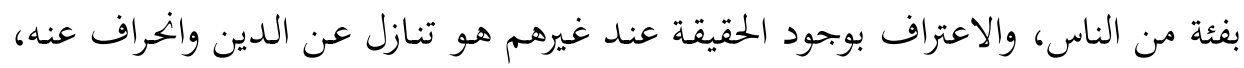

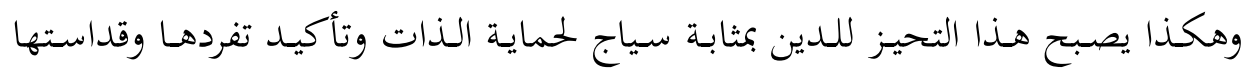

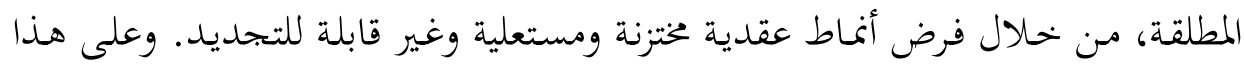

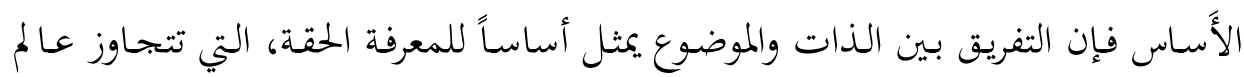
الأشخاص إلى عالم الأفكار.

من سمات الفكر الديني المغالي التحيّز المطلق للذات، فهو يقوم على رؤيـة نسقية

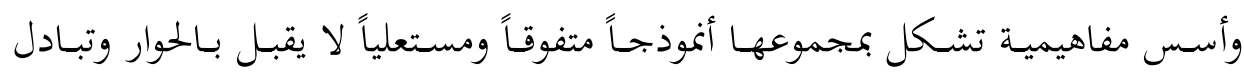

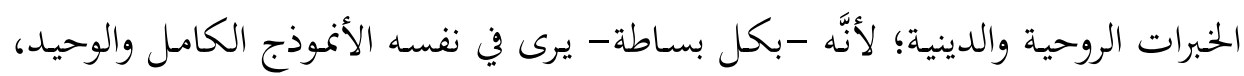
وكل مـا عـداه ليس إلا صسوراً للباطل، أو في أحسـن الأحسوال مظـاهر منقوصـة ومزيفـة.

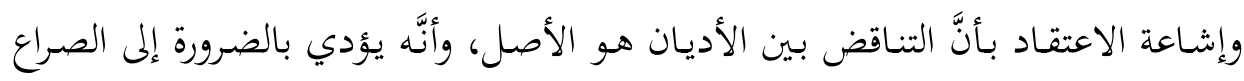

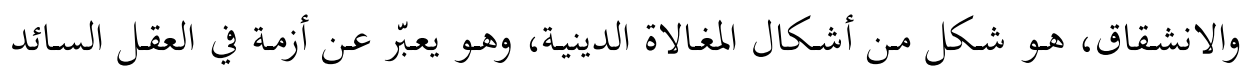
الذي يلغي التفكير الحر، ويقلل من احترامنا للرأي الآخر. 


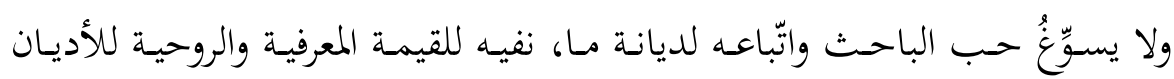

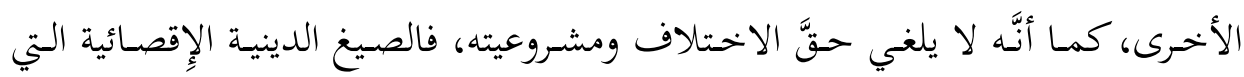

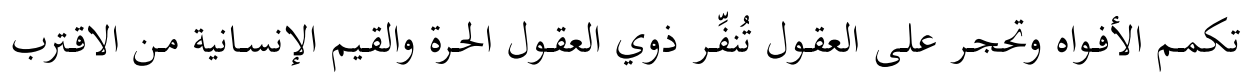

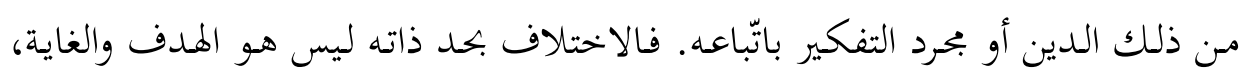

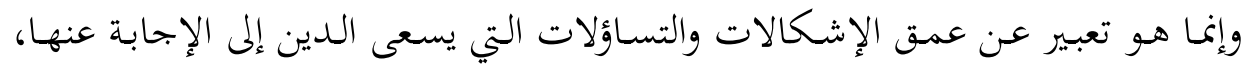

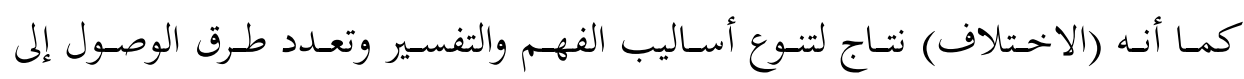

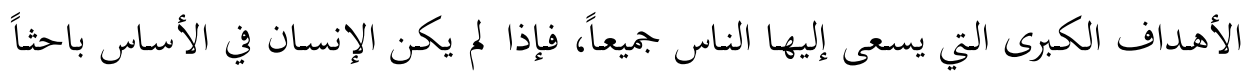

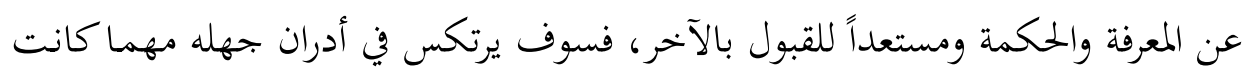
ديانته.

إنّ الاعتراف بمشروعية الاختلاف في الفكر الديني ينبغي أن يكون أمراً بديهياً، سواءً

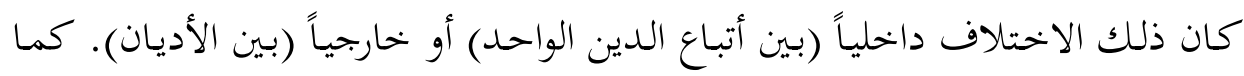

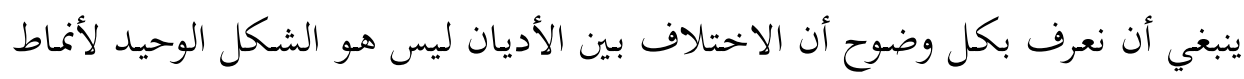

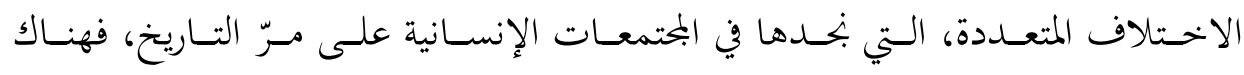

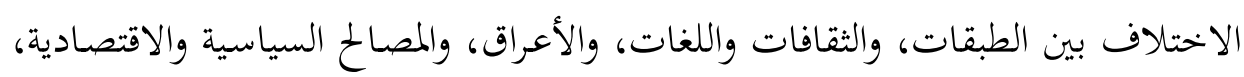

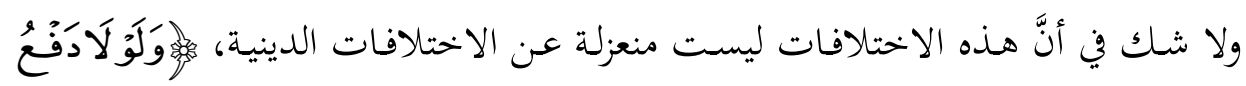

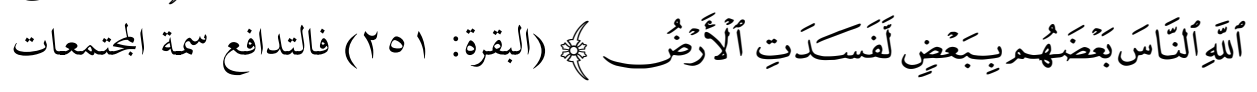

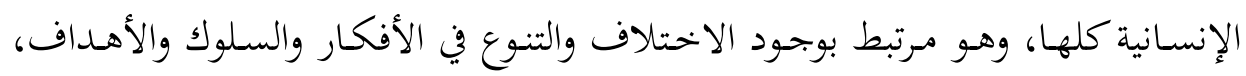

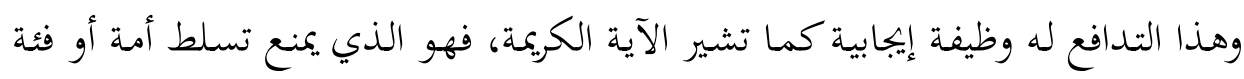

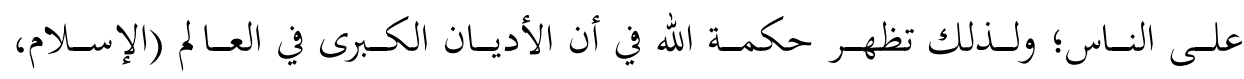

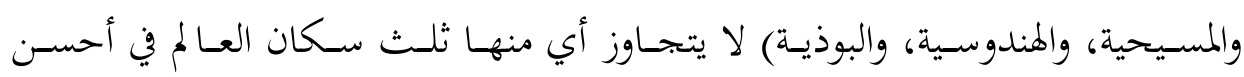
الأحوال! المبحة.

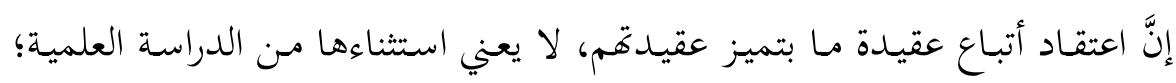

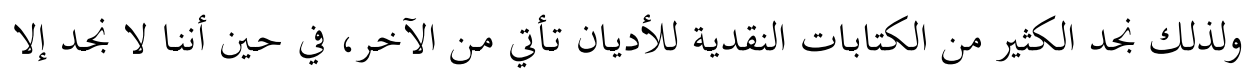

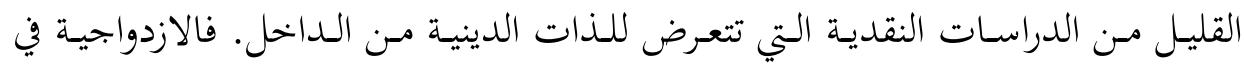


دراسـة الأديـان تُقِوّض مصـداقية المـنهج، وتحول دون فهم طبيعـة الفكر الديني وتطوره وعلاقته بالأسباب والظروف التاريخية التي أثرت في أتباع الأديان وأدت بهم إلى الاعتقاد بمعتقدات دينية محددة.

ولا يشك أحسد في ضرورة الإقبال على فهم المنجزات العلمية واستيعابها عند الأمم الأخرى، إلا أنَّ الكثيرين يحجمون عن تفهم أفكار تلك الأمسم الدينية وخبراتها الروحية، أو الاعتراف بما تمثله من أهمية في حياقم، وكأننا عندما نقرّ بأهمية دين آخر وإبحازاته عند إند أهله فإننا سننزلق بعيداً عن ديننا وتراثنا الخاص. فاختزال التراث الديني الإنساين بجملة من المقررات النهائية التي تسمه بالكفر والجهل، أو النقص والسذاجة في أحسن الأحوال، لن يرتقي بالمعرفة الإنسانية، ناهيك عن القيم الأخلاقية والإنسانية.

\section{المطلب الثاني: الموضوعية ونسبية المعرفة الدينية}

إنَّ الاعتراف بنسبية المعرفة الإنسانية عموماً يجعلنا ننفتح باستمرار على آفاق المعرفة البحهولة، ونتواضع أمام ما استطعنا الوصول إليه، دون أن ندَّعي المعرفة المطلقة والنهائية. فالحقيقة المطلقة-وإن كنا نؤمن بوجودها- إلا أننا لا نزعم بشكل من الأشكال أنَّ فهمنا

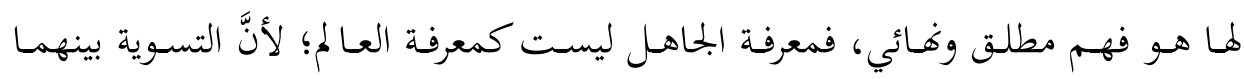

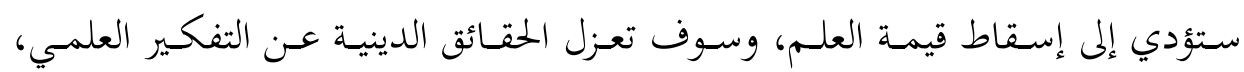

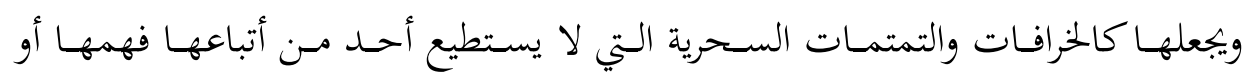
اكتشاف ضلاله فيها.

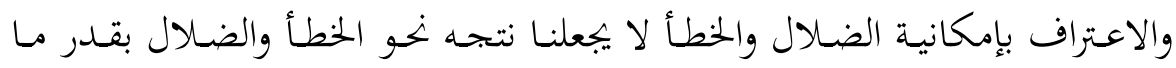
يجعلنا نسعى إلى الارتقاء بمعارفنا ومواصلة البحث والتعلم فالهداية التي وهبها الله لنبيه لم لم

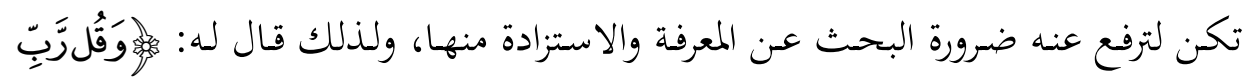

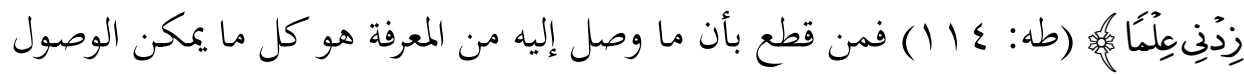
إليه، فهذا يدّعي مـا ليس له وفوق وسعه البشري. وفي هذا السياق يقول الدكتور عبد

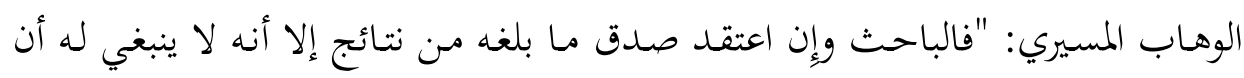


يعتقد أن أحكامه (المتحيزة) هي الحكمى النهائي المطلق؛ إذ إن أحكامه هي أولاً وأخيراً

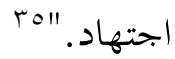

إنَّ المؤمن هو مشروع بحث وتدبر مستمر، يسعى إلى المعرفة وينقب عنها في نفسه لئه

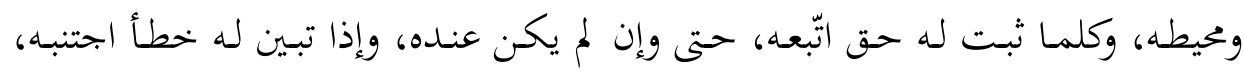

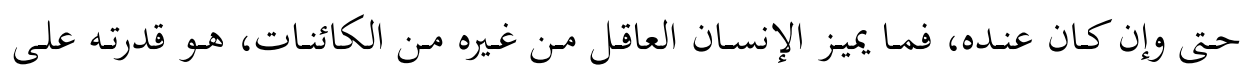

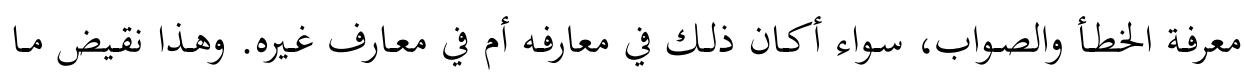

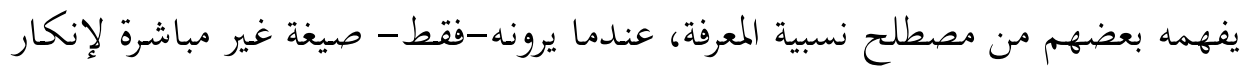
الحقائق الدينية بعمومها.

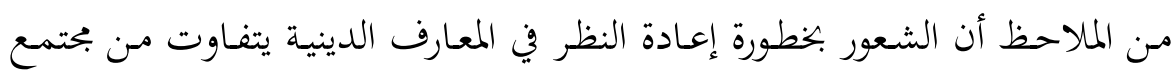

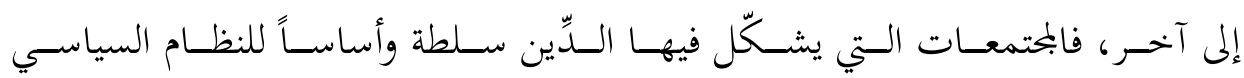

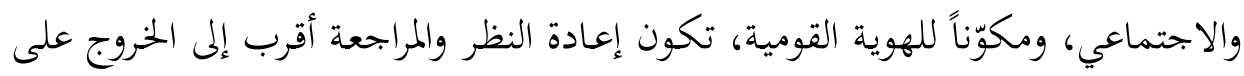

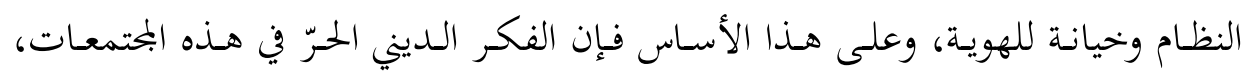

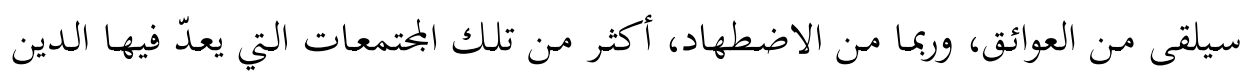

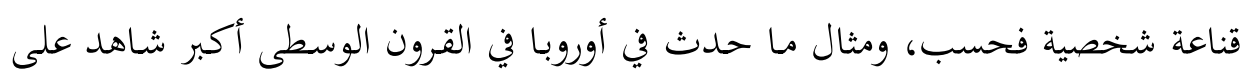
ما نودّ الإِشارة إليه.

وقد التفت بعض العلماء المسلمين القدماء إلى تلك العلاقة التي تربط بين المعرفة

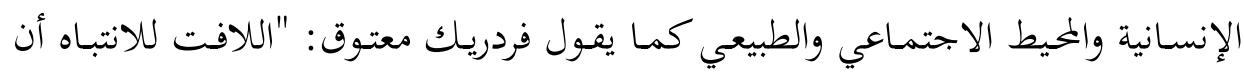

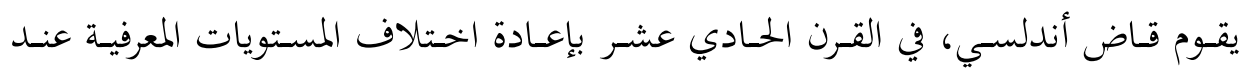

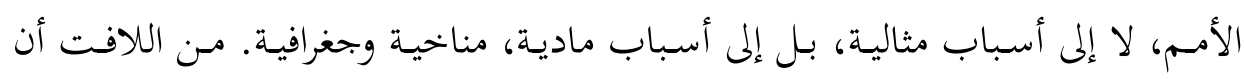

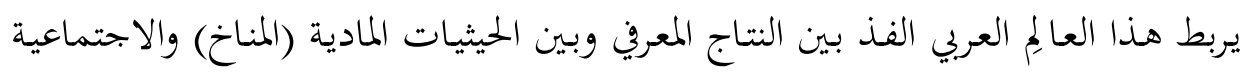

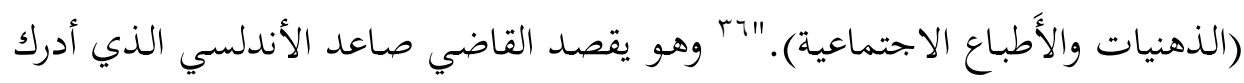
مدى تأثير المحيط المناخي والاجتماعي في تكوين المعرفة الإنسانية. 
وفي الوقت الذي أكـد لنـا البحـث العلمي العديـد مـن الأخطلاء التي كـان القـدماء يقعون فيها فيما يتعلق بالعلوم الطبيعية، فإننا نسير غافلين غير مكترثين بإعادة النظر في

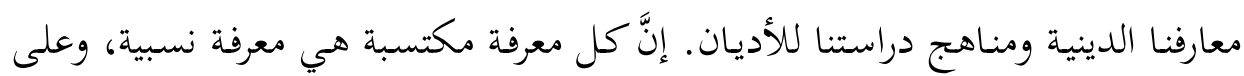
قـدر اجتهاد المكتسـب يكون نصيبه مـن المعارف والمعاني، وإذاكانت العلوم الإنسانية

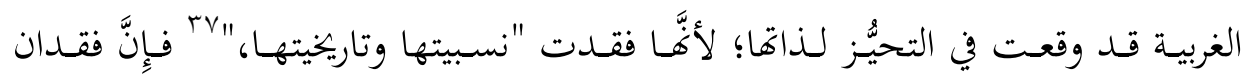
الإحساس بنسبية معارفنا الدينية وتصوراتنا ودراساتنا العقدية، إنما يعبّر عن جوهر ذلك

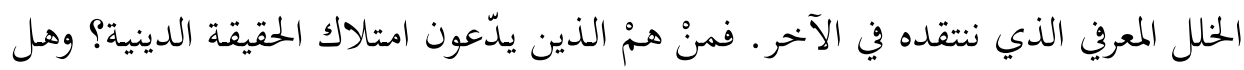
تراهم يختلفون في جوهر تفكيرهم عن غيرهم؟!

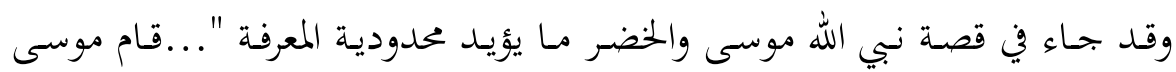

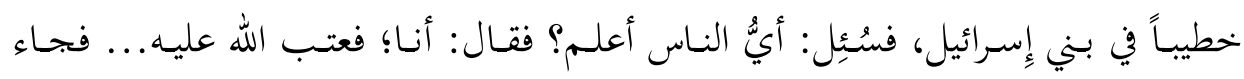

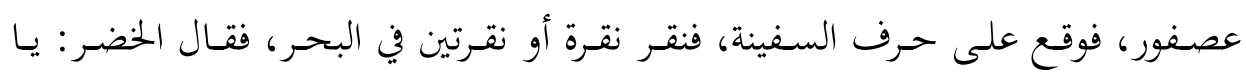

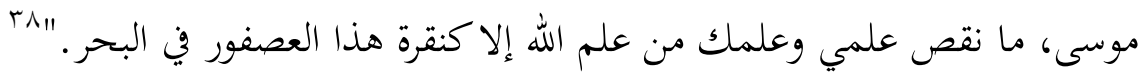
ويؤكـد اشـتمال القـرآن الكـيم على ذكر قصص الشعوب وتـاريخ الأنبيـاء الأهميـة

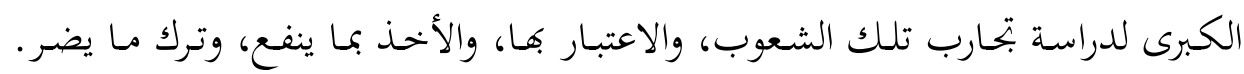

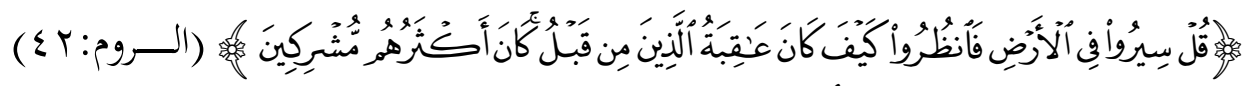

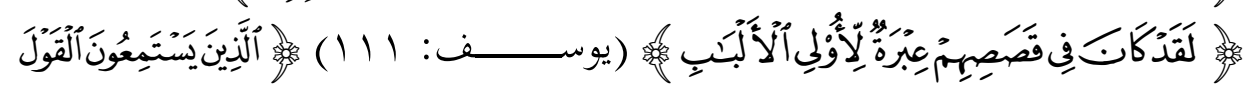

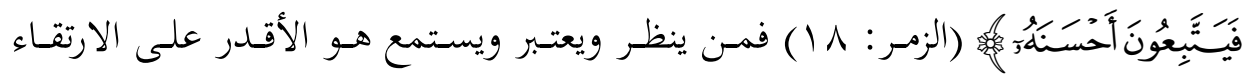

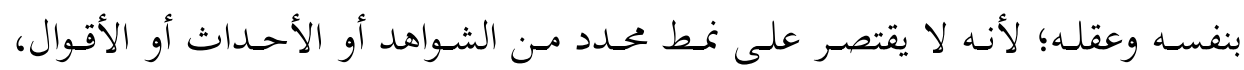
ويلحظ أنَّ "القول" في الآية الأخيرة هو لفظ عام يشمل جميع البحالات الفكرية والمعرفية، والاستماع يسبق الاتبّاع، فعلى قدر الإحسان في الاستماع يكون الإحسان في الاتّاع. وفي تأصيل هذا المعنى يقول الإمـام الطبري: "الذين يستمعون القول مـن القائلين،

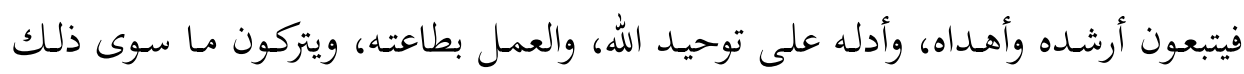


مـن القول الذي لا يدل على رشاد، ولا يهدي إلى سداد." مج" ويقول ابن عطية: "كلام

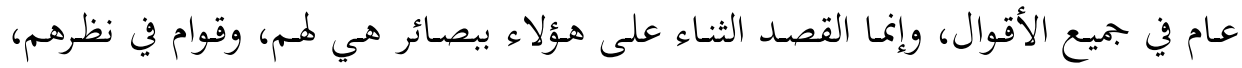
حتى إهم إذا سمعوا قولاً ميزوه واتبعوا أحسنه." "•؛ ويقول ابن الجهوزي: "وفيه ثلاثة أقوال:

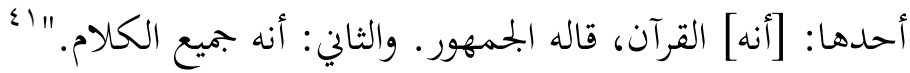

ويقـول الإمـام الـرازي كلامـاً جمسيلاً يعمـق فيـه العلاقـة بـين الاسـتماع والاسـتدلال

العقلي: "واعلم أنَّ هذه الآية تدل على فوائد: الفائدة الأولى: وجوب النظ النظر والاستدلال؛ وذلك لأنَّه تعالى بيّن أنَّ المداية والفلاح مرتبطان بما إذا سمع الإنسان أشياء كثيرة، فإنَّهـ

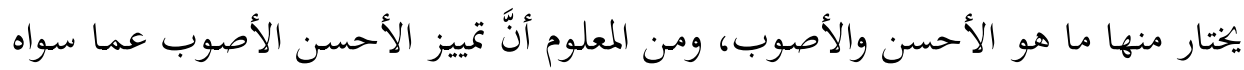

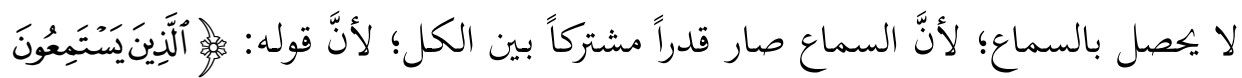

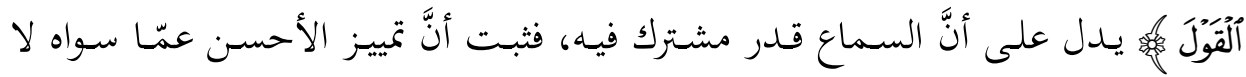

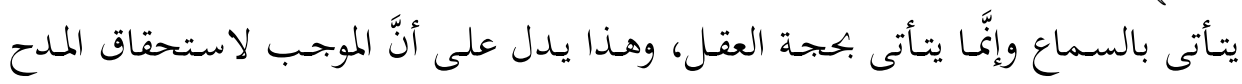

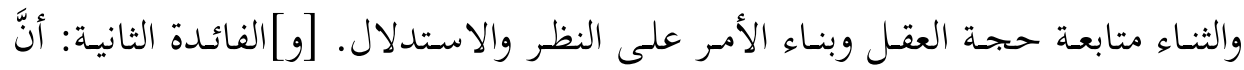
الطريق إلى تصحيح المذاهب والأديان قسمان: أحدهما: إقامة الحجة والبينة على صحته وله على سبيل التحصيل، وذلك أمر لا يمكن تحصيله إلا بالخوض في كل واحدةٍ من المسائل

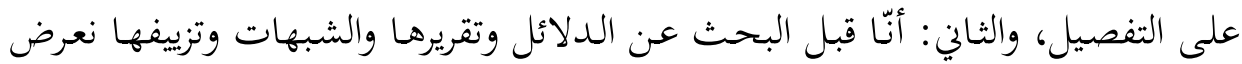

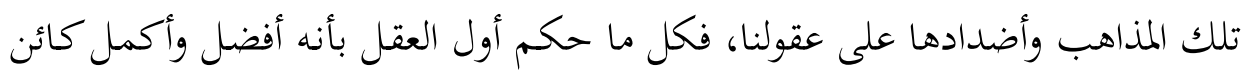

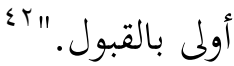

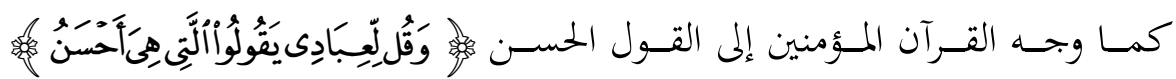

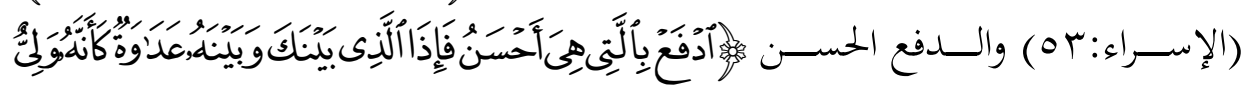
ج" الطبري، محمد بن جرير. جامع البيان في تفسير القرآن، تحقيق: أحمد محمد شاكر، دمشق: مؤسسة الرسالة،

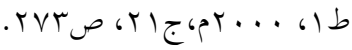

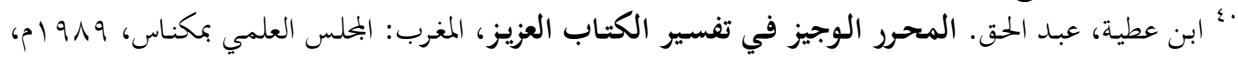
1؛ ابن الحوزي، عبد الرحمن. تفسير زاد المسير في علم التفسير، بيروت: المكتب الإسلامي، طس، ع ــ اهـ،

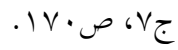

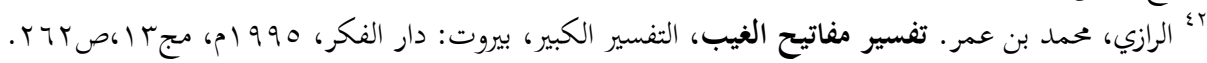




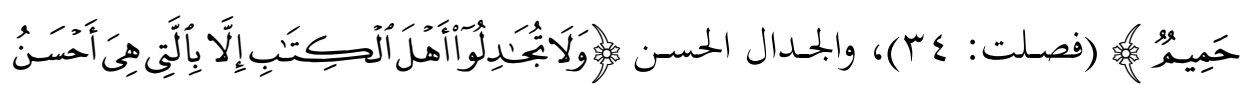

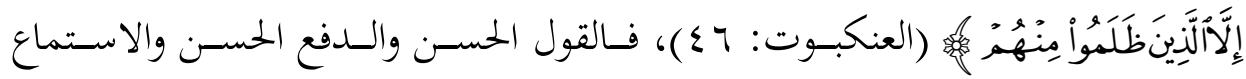

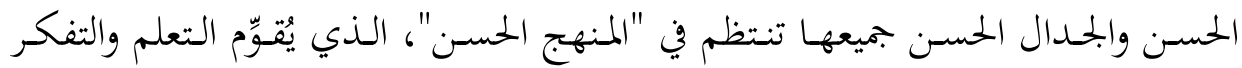

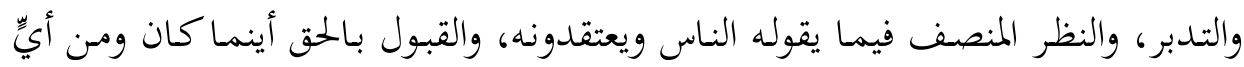

المبحث الخامس: مظاهر غياب الموضوعية وأسبابها في دراسة الأديان. المطلب الأول: مظاهر غياب الموضوعية في دراسة الأديان

من الصعوبة بمكان الإحاطة بكل مظاهر غياب الموضوعية في دراسة الأديان، إلا أنه

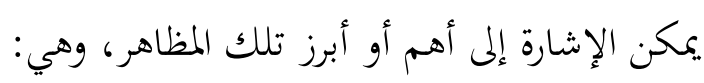

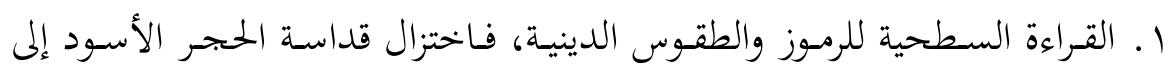

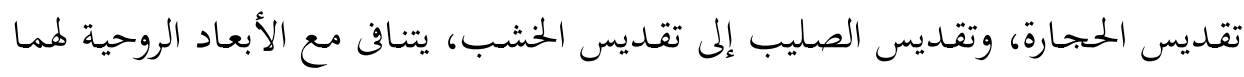

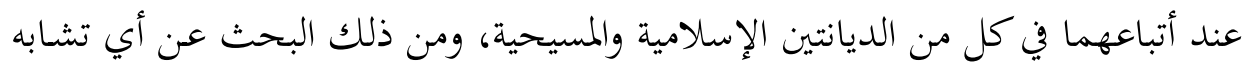

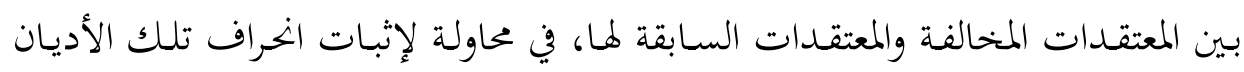

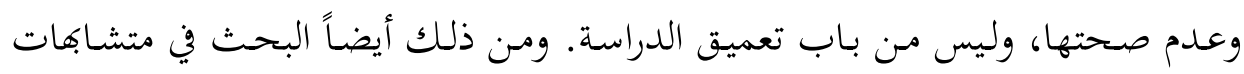

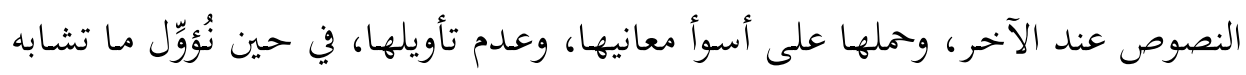

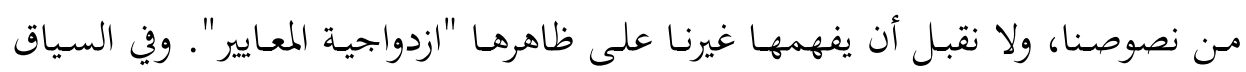

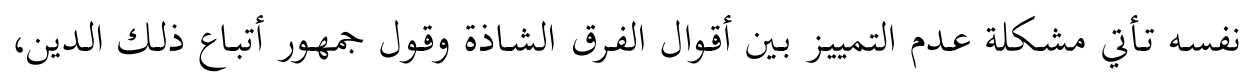

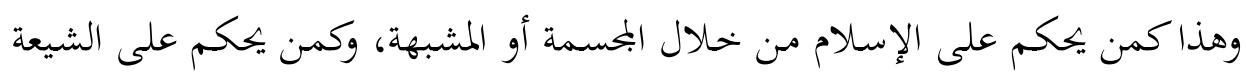
من خلال الغرابية والسبئية.

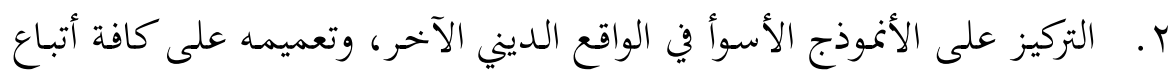

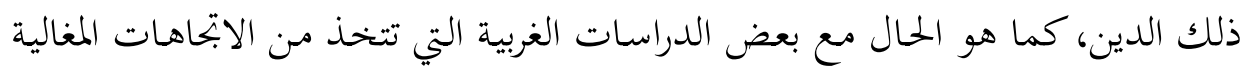

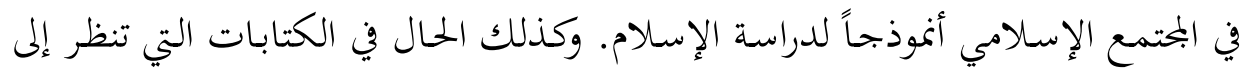

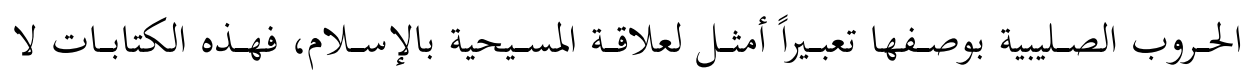


تختلف في مضموها المعرفي عن تلك الكتابات المناهضة للإِسلام، التي ترى الإرهاب مبدأ

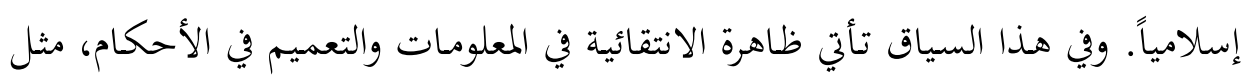
تعميم الضعيف والشاذ من أقوال بعض الفرق المنتسبة لهذا الدين أو ذاك على كافة أتباع الدين.

ب. الحرص على نقد الأديان الأخرى أكثر من الحرص على معرفة أفكارها وقيمها

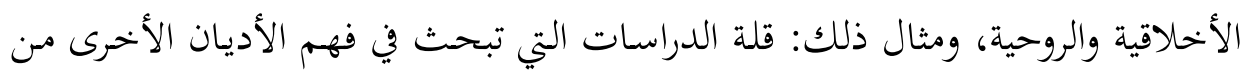

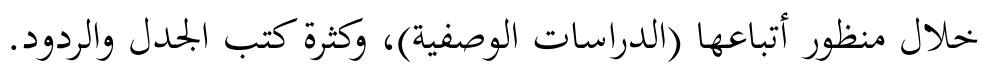
ع. إنكار الحقائق التاريخية، أو تشويهها، أو اختلاق أحسداث أو شخصيات ليس

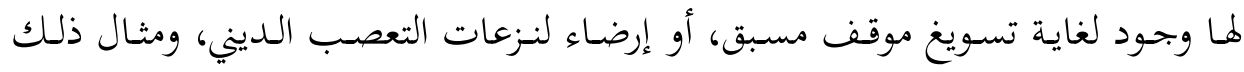
محاولات بعض المستشرقين نفي نبوة محمد عليه الصلاة والسلام. ه. عـدّ التشـابه في الأفكـار أو المعتقــات أو الكتابـات المقدسـة للأديـان الأخهرى دليلاً على وضعيتها وعدم صحتها، مقابل استعمال أي تشابه بين دين الباحث والأديان

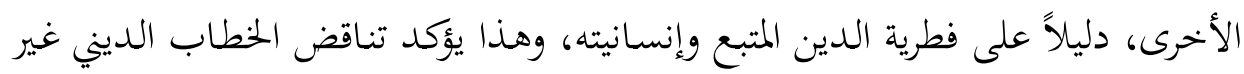
الموضوعي مع بدهيات العقول.

ج. إعطاء الأولية للنقد، مع إهـال بناء التصورات العلمية الموضوعية عن الأديان،

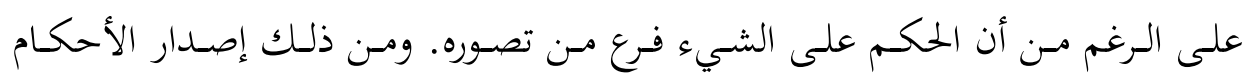

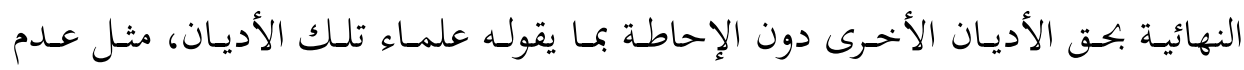

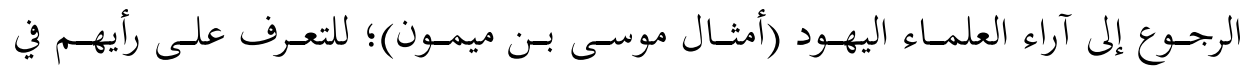

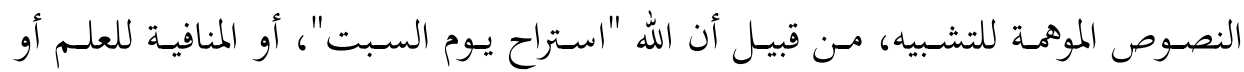
الحقائق التاريخية.

V. عـدم امـتلاك المؤهلات العلميـة لنقـــ التصـورات الدينيـة الأخهرى، لا سيّما وأنَّ

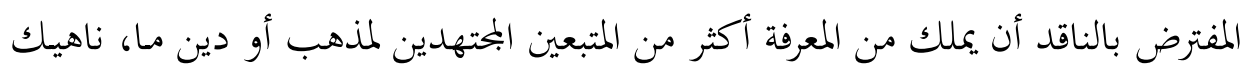

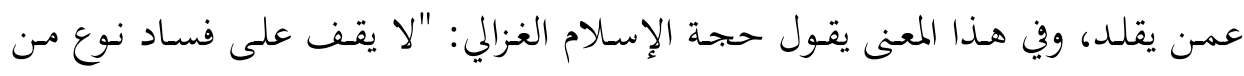
العلوم من لا يقف على منتهى ذلك العلم، حتى يساوي أعلمهم في أصل العلم، ثم يزيد

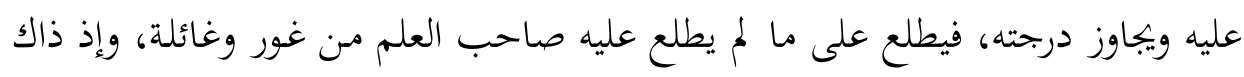


يمكن أن يكون مـا يدعيه مـ فساد حقاً." بـأومن غياب المؤهلات العلمية عدم معرفة

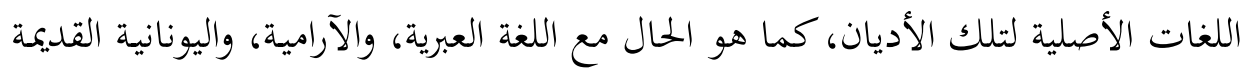
في دراستنا لليهودية والمسيحية، وما يترتب على ذلك من آراء تتناقض والمعرفة العلمية. م. احتكار المعرفة الدينية واختزالها بمنظومـة دينية بعينها، وهـذا من قبيل "ادعـاء التحدث عن الدين بصفة عامة، في حين أنه يتحدث عن دين بعينه، أو يدّعي التحدث واتِ

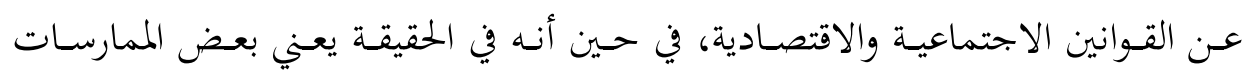

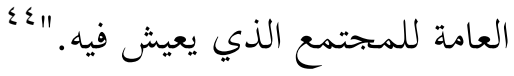

9. عدم الرجوع إلى المصادر الأساسية المعتمدة عند أتباع تلك الأديان، والاقتصار

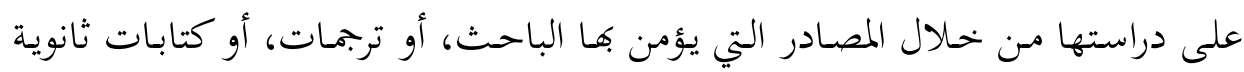

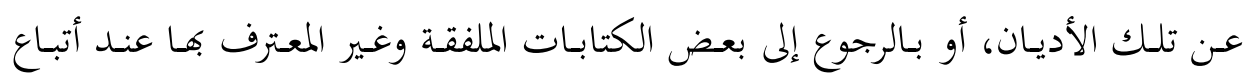
ذلك الدين، كما هو الحال مع كتاب "بروتوكولات حكماء صهيون"، الذي اتخذه العديد من الكُتَّاب منطلقاً أساسياً في دراستهم للديانة اليهودية.

وبناء على ما سبق، يجار بالمتعاملين مع هذا النوع من الدراسات، أن يأخذوا بعين

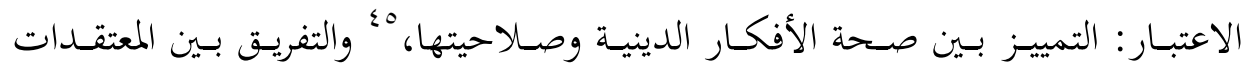

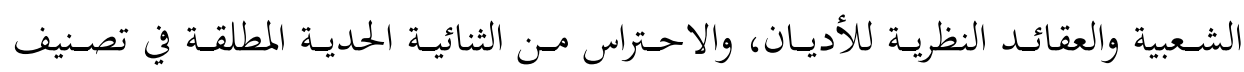

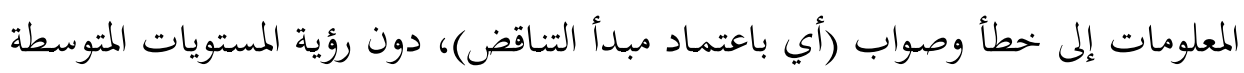
بين المتناقضات.

\section{المطلب الثاني: أسباب غياب الموضوعية في دراسة الأديان}

\section{أولاً: الأسباب النفسية}

وهي عديدة منها عدم قدرة الباحث على التجرد من ميوله النفسية ومصالحه وقيمه

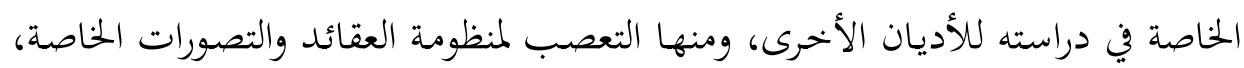

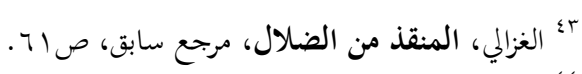

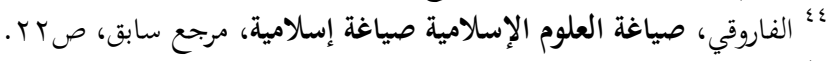

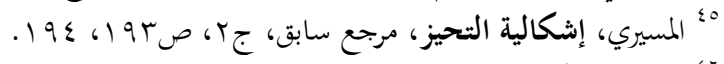

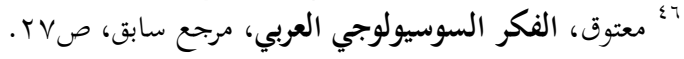


وما تنطوي عليه من أفكار ومعايير وأحكام؛ مما يحول دون فهمه للأديان الأخرى على مـا هي عليه في الواقع . ومـن هـذه الأسباب أيضـاً شعور الباحثث المتـدين بخطورة التأثر المحتمل للانفتاح الموضوعي على دراسة الأديان والعقائد المخالفة؛ مما يدعوه إلى المسارعة

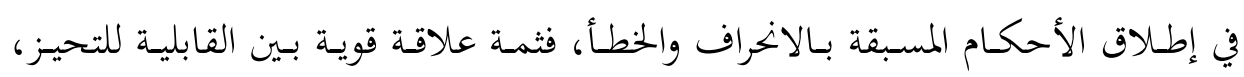
وزيادة الشعور بالخطر الخارجي، ومنها الرغبة في تمجيد الذات، وذلك حين يجعل الإنسانُ

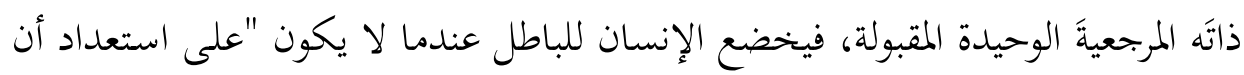

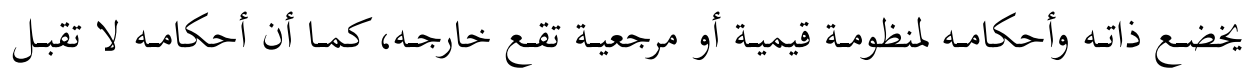

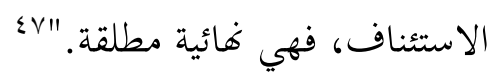

وأخيراً فإن اتبّاع الهوى، من أشد نقائض الموضوعية، فالباحث الموضوعي ينبغي أن

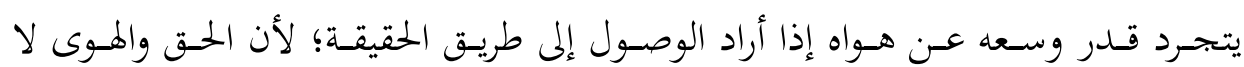

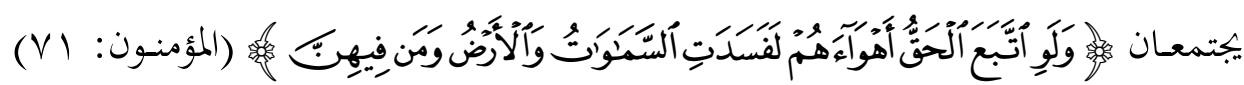

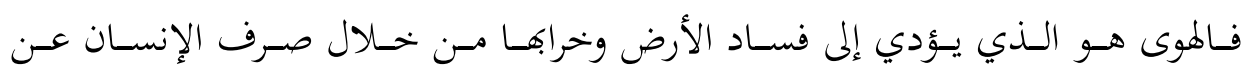
الانسجام مع قوانين الطبيعة، ويمول دون قبوله بكل ما يظنه مناقضاً لتلك الأهواء، وهذا

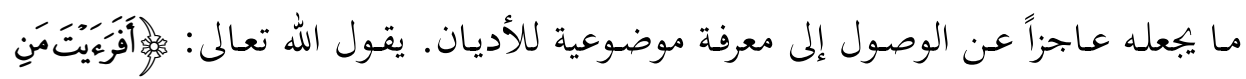

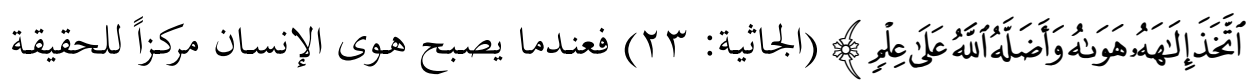

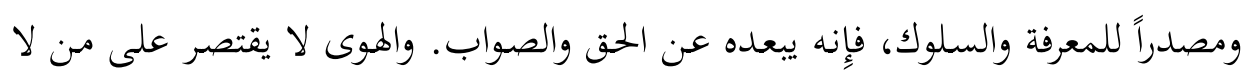

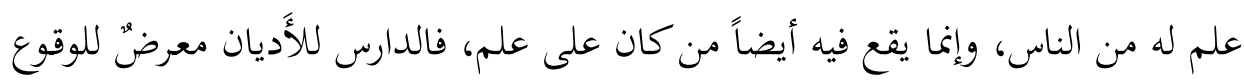

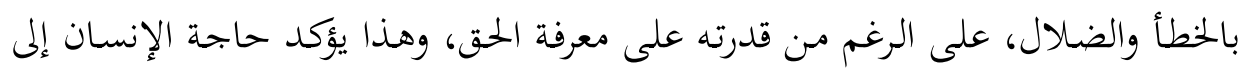
دوافع صحيحة تحثه على الارتقاء بعلمه، ومغالبة أهوائه ورغباته في نطاق سعيه للمعرفة.

\section{ثانياً: الأسباب الفكرية}

إذاكان الخللل في عـالَّ الأفكار هـو الأكثر صعوبة مـن حيـث إمكانيـة اكتشافه أو

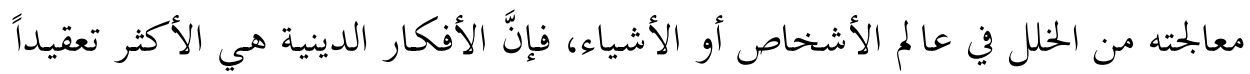




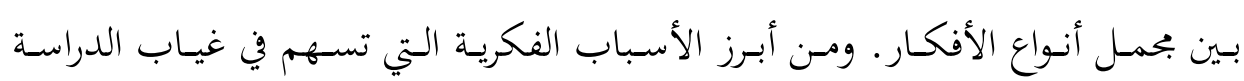

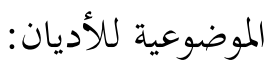

ا ـ تأثير المفكرين القدامى في عقل الباحث؛ إذ يصبح ناقلاً وعارضاً لآراء المفكرين

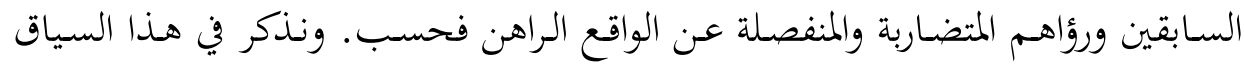

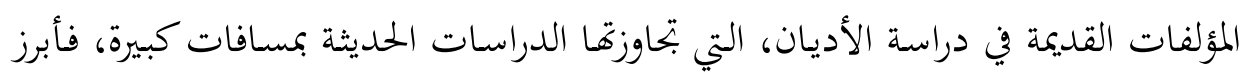

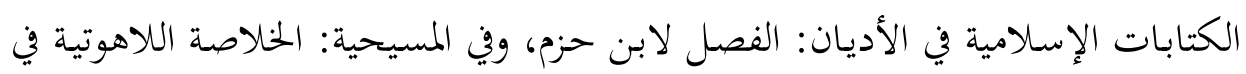

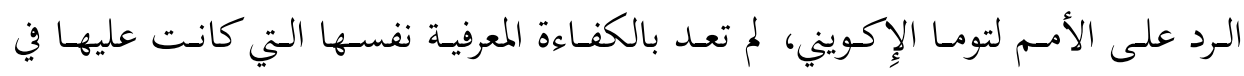

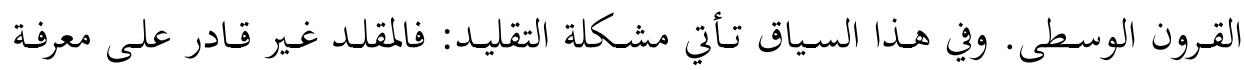

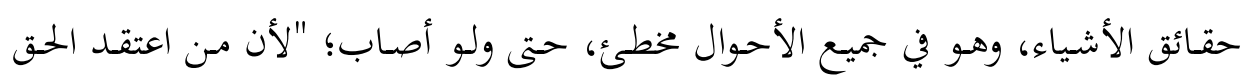

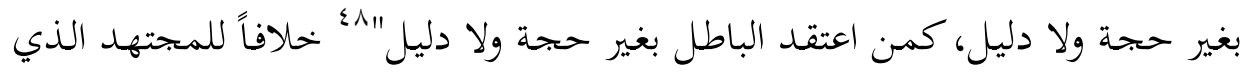
يؤجر، حتى وإن أخطأ.

r. عدم توفر وسائل منهجية ذات مصداقية محايدة لفهم القضايا الدينية ودراستها،

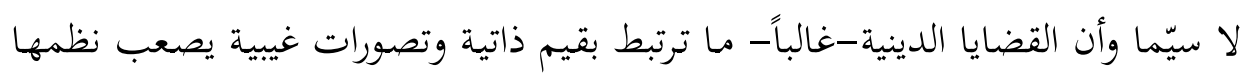
على شكل قوانين، كتلك التي يدرسها علماء الطبيعة.

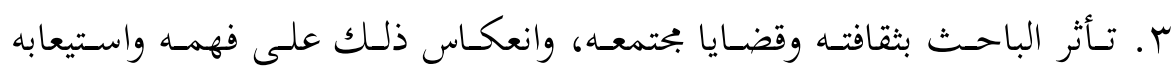

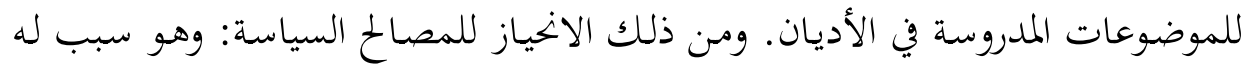

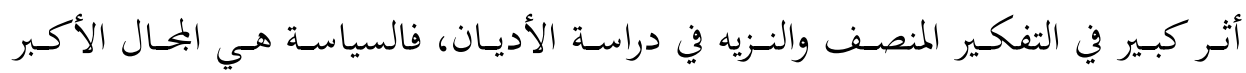

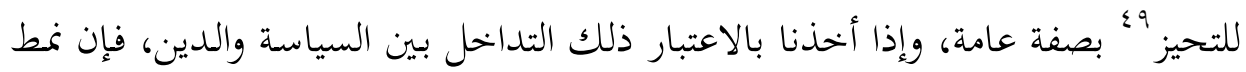
التحيز يصبح أكثر تعقيداً، وقد لا يستطيع الكثير من الناس أن يتنبه إليه.

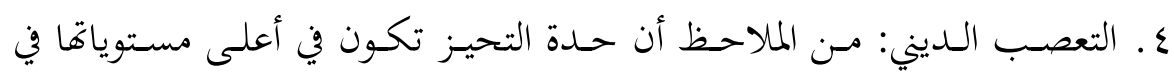

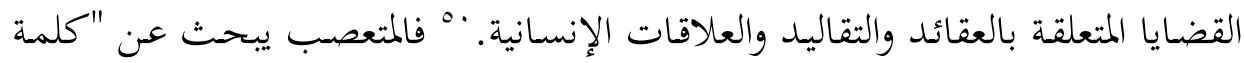
^؛ ابن المرتضى، المنية والأمل في الملل والنحل، تحقيق: عمد جواد مشكور، بيروت: دار الندى، طץ، ـ99 (1م،

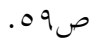

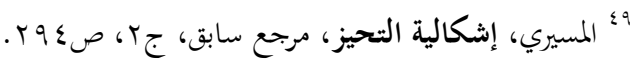

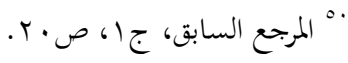




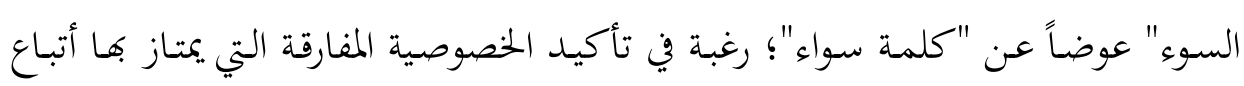

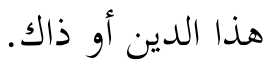

ه. عـدم قـدرة عـدد غير قليـل مـن دارسي الأديـان على تحييد مبـادئهم الدينيـة

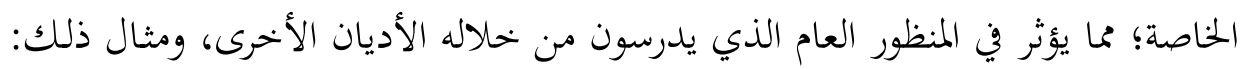

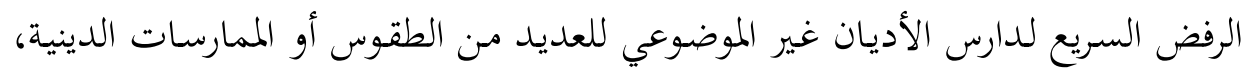

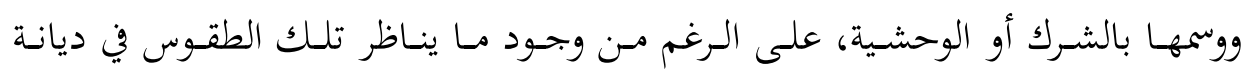

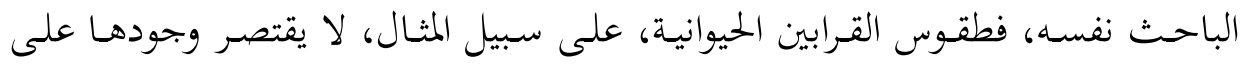

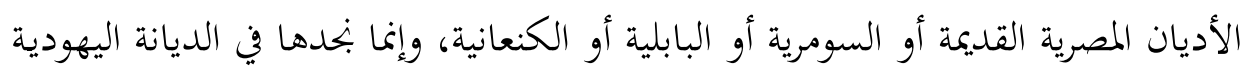

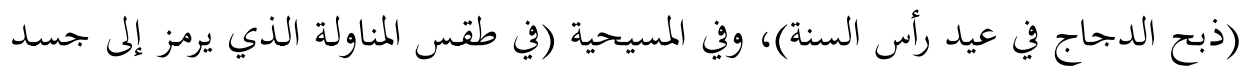

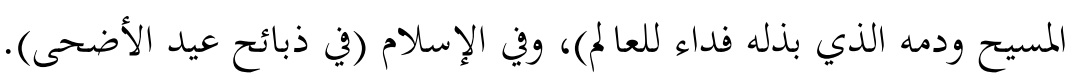

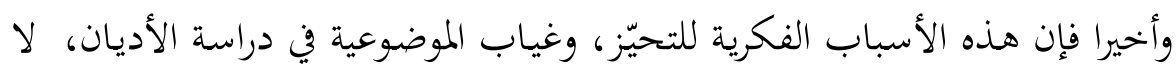

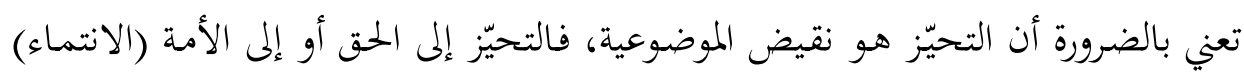

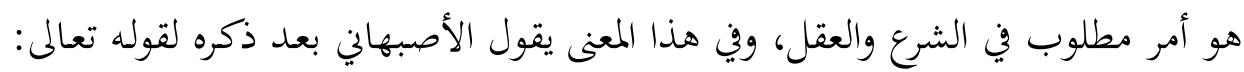

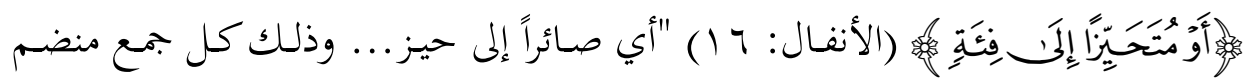

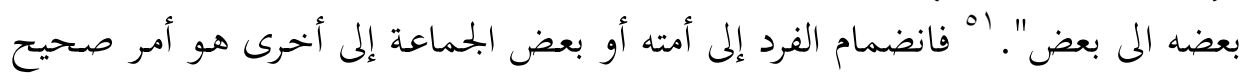

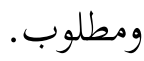

\section{المطلب الثالث: المسلمات وغياب الموضوعية في دراسة الأديان}

تتنافن الدراسة الموضوعية للأديان مع ذلك المنهج الذي ينطلق من المسلَّمات وينتهي

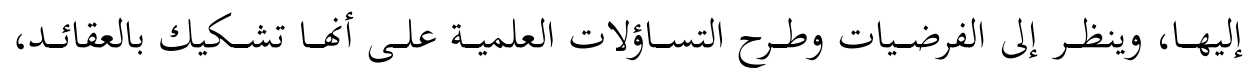

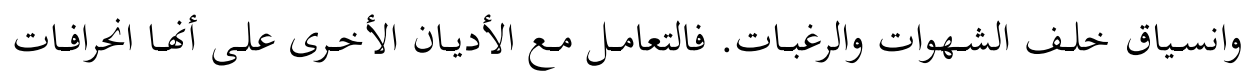

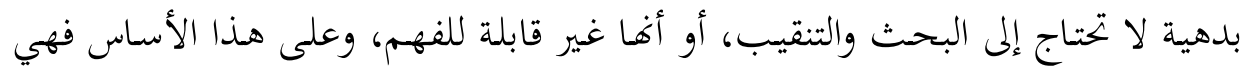

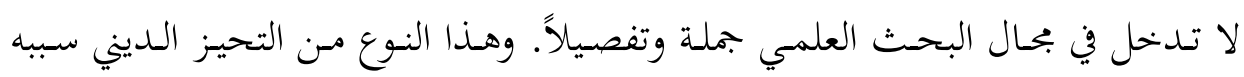


التسطيح والتبسيط للقضايا الدينية، التي هي في الواقع من أكثر القضايا تعقيداً وتركيباً وامتزاجاً بتطور البحتمعات الإنسانية.

ينبغي لدارس الأديان أن يدرس الأفكار والمعتقدات الدينية؛ لمعرفة حقائقها وأصوها

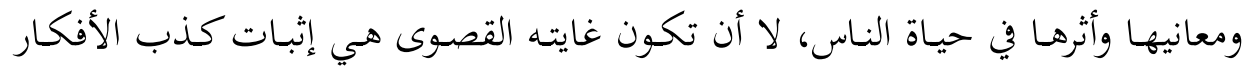

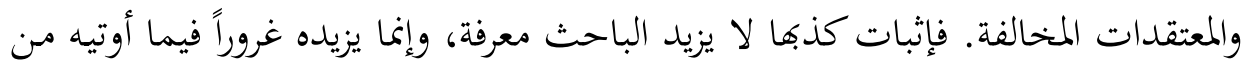

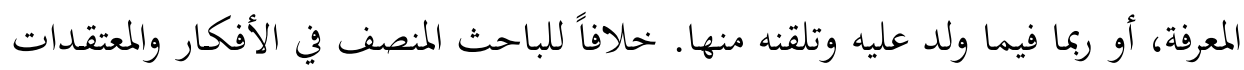

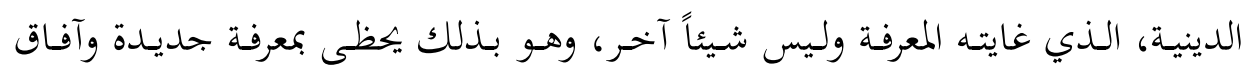
أوسع، تزيده علماً وتواضعاً، وتحفز سعيه ووعيه.

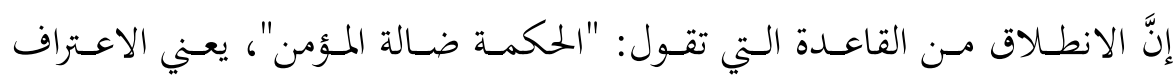

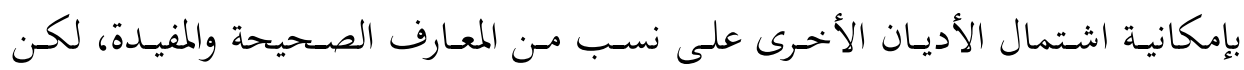

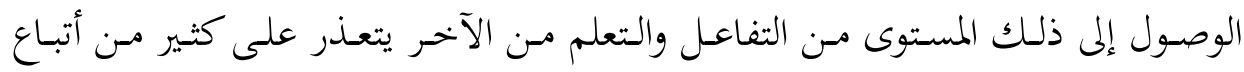

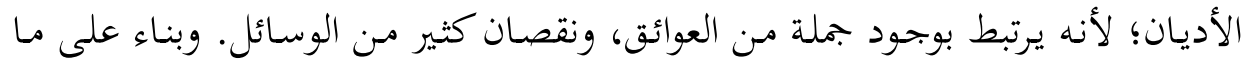

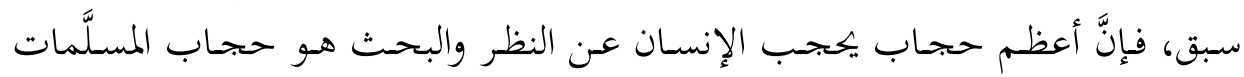

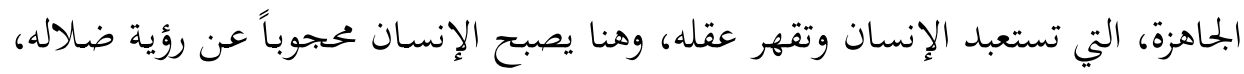

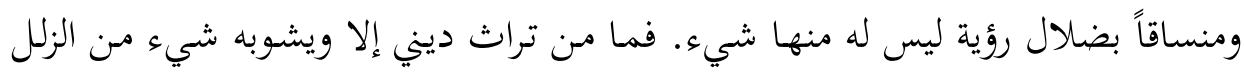

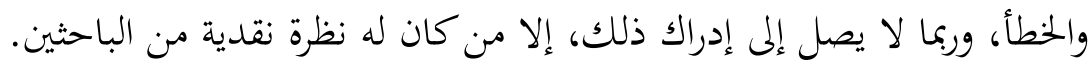
وما من شك في أنَّ تصور الأفكار المخالفة في عقولنا يتأتز بجملة تصوراتنا الخاصة،

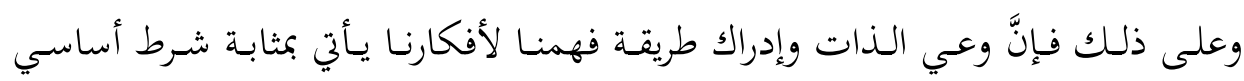

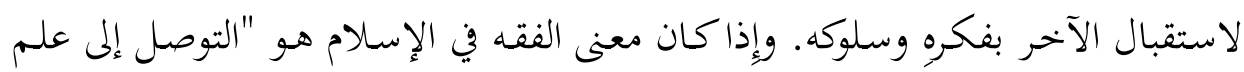

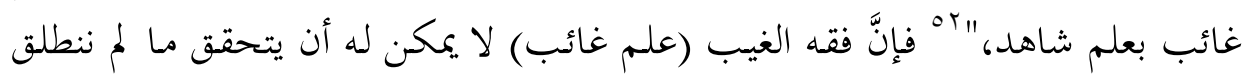

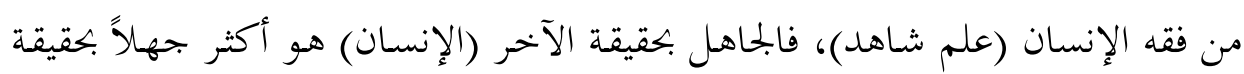

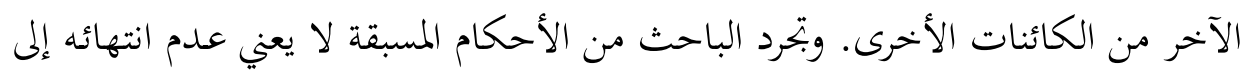

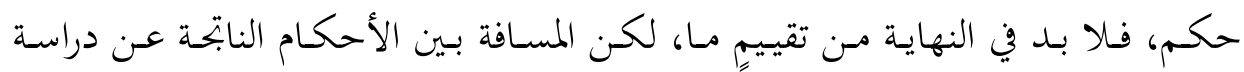

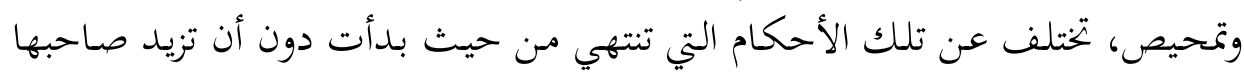
شيئاً من المعرفة. 
خاتمة:

اشتمل القـرآن على منطلقـات عقديـة وأخلاقيـة تؤسس لمـنهج موضـوعي قويم في

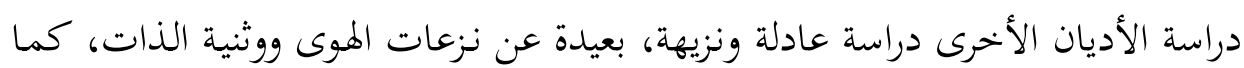
استطاع الفكر الإسلامي أن يقدم نماذج مبكرة للدراسات الدينية الموضوعية. وثمة فارق كبير بين دراسة الأديان دراسة جدلية تمدف إلى إثبات تفوق ديانة معينة

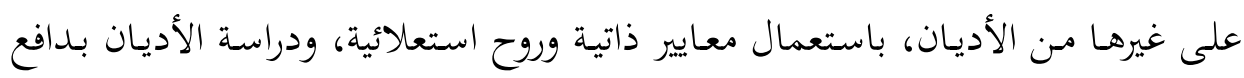
علمي موضوعي يهدف إلى فهم الآخر، وتكوين صورة واضحة له بوصِيفِهِ إنساناً مُكرَّهاً

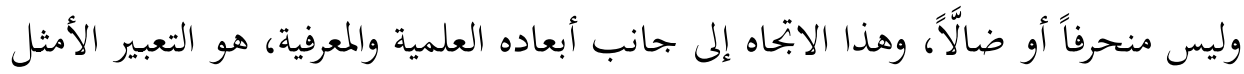

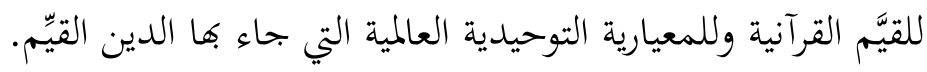
ليسـت الموضـوعية في دراسـة الأديـان بتريـــاً للإنسـان عـن إنسـانيته، ولا اقصـاء

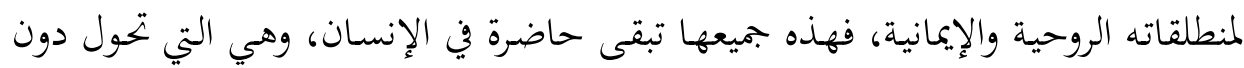

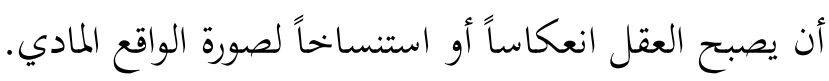

إنّ الموضوعية في دراسة الأديان ليست بمعزل عن إشكالات الموضوعية التاريخية، التي

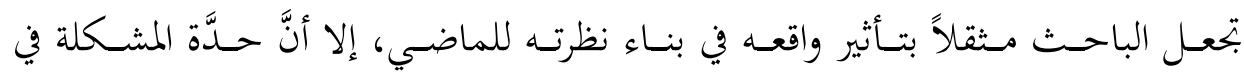

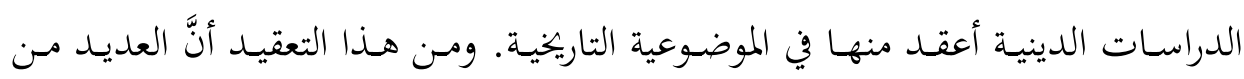

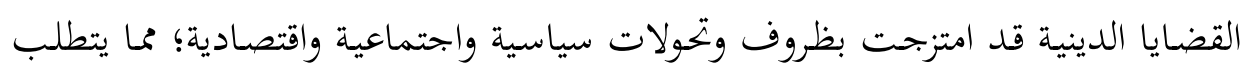
من الباحث الموضوعي معرفة أثر الظروف والتحولات في تشكيل بنية التحيز في دراسة فئل الأديان.

ينبغي التنبه إلى أثثر التحيز في موقفنـا مـن الأديان الأخرى، وتصـنيفها إلى وضعية

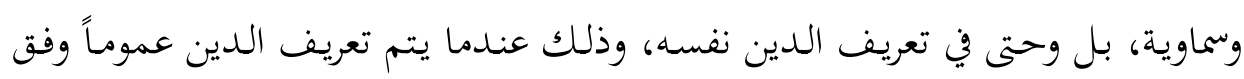

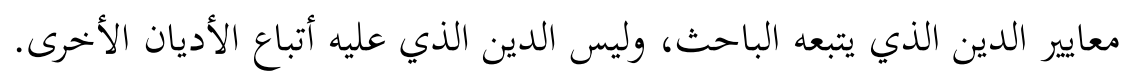


عامر الحائي

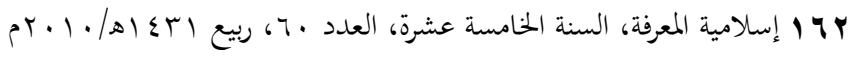

المشكلة الأساسية أمام الدراسة الموضوعية للأديان تتجاوز وجود أحكام وتصورات

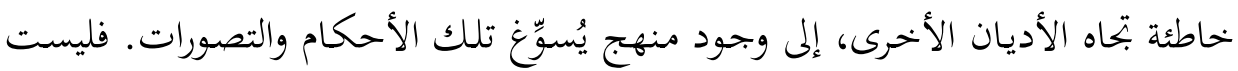

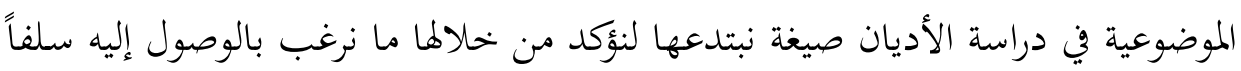

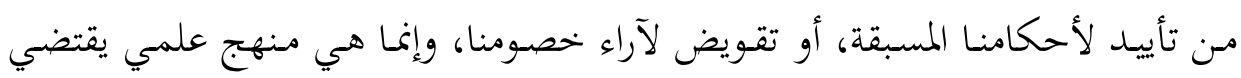
تجرد الباحث من رغباته وأحكامه المسبقة.

ولا يمكسن لغيـاب الموضـوعية أن يُسوََّغ بمسـوغات دينيـة، وإنمـا ينبغي على الباحـث

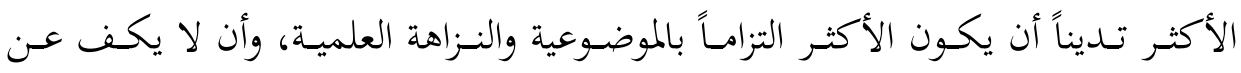

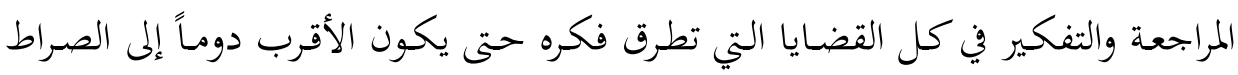

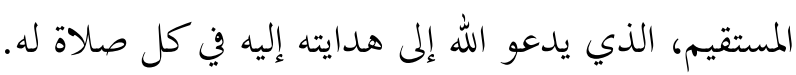

